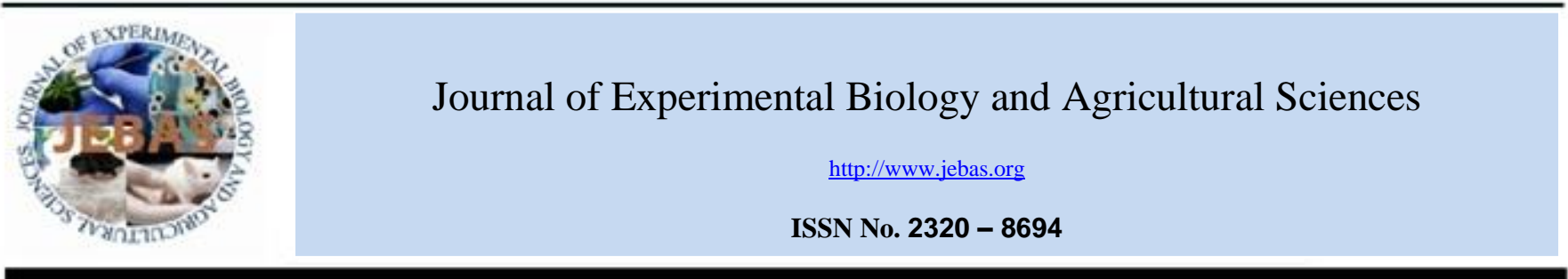

\title{
NOVEL CORONAVIRUS (SARS-COV-2): MOLECULAR BIOLOGY, PATHOGENESIS, PATHOBIOLOGY AND ADVANCES IN TREATMENT OF COVID-19 PATIENTS- AN UPDATE
}

\author{
Sonam Tripathi ${ }^{1}$, Megha Katare Pandey ${ }^{2}$, Yashpal Singh Malik ${ }^{3}$, Muhammad Bilal $^{4}$, \\ Kuldeep Dhama ${ }^{5}$, Wanpen Chaicumpa ${ }^{6}$, Ram Chandra $^{1}$ *
}

\footnotetext{
${ }^{1}$ Department of Microbiology, School of Environmental Sciences, Babasaheb Bhimrao Ambedkar University, (A Central University) Vidya Vihar, Raebareli Road, Lucknow-226025, UP., India

${ }^{2}$ Department of Veterinary Pathology, College of Veterinary Science, Durg- 491001, Chhattisgarh, India

${ }^{3}$ Division of Biological Standardization, ICAR-Indian Veterinary Research Institute, Izatnagar, Bareilly- 243 122, Uttar Pradesh, India

${ }^{4}$ School of Life Science and Food Engineering, Huaiyin Institute of Technology, Huaian 223003, China.

${ }^{5}$ Division of Pathology, ICAR-Indian Veterinary Research Institute, Izatnagar, Bareilly- 243 122, Uttar Pradesh, India

${ }^{6}$ Center of Research Excellence on Therapeutic Proteins and Antibody Engineering, Department of Parasitology, Faculty of Medicine Siriraj Hospital, Mahidol University, Bangkok 10700, Thailand
}

Received - November 07, 2020; Revision - November 30, 2020; Accepted - December 20, 2020

Available Online - December 30, 2020

DOI: http://dx.doi.org/10.18006/2020.8(6).683.708

\section{KEYWORDS \\ SARS-CoV-2 \\ COVID-19 \\ Molecular biology \\ Pathobiology \\ Treatment}

\section{* Corresponding author}

E-mail: prof.chandrabbau@gmail.com (R. Chandra)

Peer review under responsibility of Journal of Experimental Biology and Agricultural Sciences.

Production and Hosting by Horizon Publisher India [HPI] (http://www.horizonpublisherindia.in/).

All rights reserved.

\begin{abstract}
The novel coronavirus (CoV), earlier named 2019-nCoV, and later as severe acute respiratory syndrome coronavirus - 2 (SARS-CoV-2) has now created havoc and panic across the globe by its severe ongoing pandemic. This virus has to date as of $23^{\text {rd }}$ November 2020, killed nearly 1.4 million persons out of more than 59 million confirmed positive cases, while spreading rapidly in more than 215 countries and territories. Taxonomically, SARS-CoV-2 has been characterized in genus Betacoronavirus, which contains non-segmented positive-sense, single-stranded (ss) RNA genome of $\sim 30 \mathrm{~kb}$. The first two open reading frames (ORFs), ORF1a and ORF1b, of SARS-CoV-2, encode 16 non-structural proteins (nsp1nsp16), whereas other ORFs encodes four main structural proteins (sp) [spike (s) by ORF2, envelope (E) by ORF4, membrane (M) by ORF5, nucleoprotein (N) by ORF9], and accessory proteins essential for the virus fitness, pathogenesis and host immunity evasion. Sequence alignments of SARS-CoV-2 with genomes of various coronaviruses showed 58\% identity in the non-structural protein (nsp)-coding region, $43 \%$ with the structural protein (sp)-coding region and $54 \%$ with the whole genome. The fulllength genome sequence of the 2019-nCoV sample showed only up to $79.60 \%$ similarity with SARS
\end{abstract}

All the articles published by Journal of Experimental Biology and Agricultural Sciences are licensed under a Creative Commons Attribution-NonCommercial 4.0 International License Based on a work at www.jebas.org.

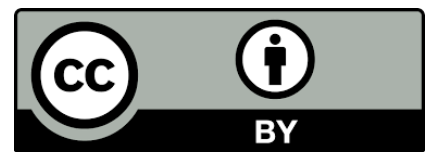


CoV, but up to $96 \%$ similarity with bat coronavirus (bat coronavirus RaTG13). This gives strong evidence that 2019-nCoV has originated from the bat. The genomic and evolutionary evidence of another coronavirus species from pangolins also show higher similarity to SARS-CoV at the wholegenome level. Apart from RaTG13, Pangolin-CoV is the most closely related CoV to SARS-CoV2. During infection, the viral $S$ protein interacts with the receptor protein of the human cell membrane, known as angiotensin-converting enzyme II (ACE2). Presently, SARS-CoV-2 vaccines and drugs are not available, for which researchers are trying hard to develop to tackle rising tide of COVID-19- pandemic. Early diagnosis, contact tracing, strict prevention and control measures, biosecurity, personal biosafety, disinfection and sanitization practices, social distancing are aiding in prevention with SARS-CoV-2 infection. Boosting immunity by intaking the balanced and nutritious food, nutraceuticals, herbs, and following physical exercises along with avoiding stress conditions enhance the fighting power of the body against SARS-CoV-2 infection and limiting the severity of COVID-19. The present article describes salient knowledge on SARS-CoV-2 structure, genomic organization, pathogenesis, pathobiology, and advances and progress being made to treat COVID-19 patients.

\section{Introduction}

The $21^{\text {st }}$ Century suddenly witnessed a new emerging virus - novel coronavirus 2019 (2019-nCoV) in December 2019 from Wuhan city of China, later named as severe acute respiratory syndrome coronavirus - 2 (SARS-CoV-2). The virus caused coronavirus disease 2019 (COVID-19) pandemic that has posed high challenges to the survival of the humans (Barbuddhe et al., 2020; Ciotti et al., 2020; Dhama et al., 2020a; Malik et al., 2020). This is the worst pandemic after the Spanish Flu pandemic of the year 1918 during which 20-50 million people lost their lives. In a short period of ten months, this virus rapidly got spread to many countries across the globe, affecting 215 countries and territories, while posing huge panic and fear among the entire population of the world owing to its severe clinical manifestations and associated mortality (Dhama et al., 2020b). COVID-19 has claimed the lives of nearly 1.4 million persons with more than 59 million confirmed $\begin{array}{llll}\text { cases as of } & 23^{\text {rd }} & \text { November } & 2020\end{array}$ (https://www.worldometers.info/coronavirus/). The ongoing COVID-19 pandemic has implicated severe public health concerns, created high socio-economic negative impacts and substantial monetary losses along with putting millions of people under forced locked down states in their homes (Ahmad et al., 2020a; Ayittey et al., 2020; Nicola et al., 2020; Lenzen et al., 2020; Yamin, 2020).

Due to the non-availability of any effective vaccine or drug, SARS-CoV-2 is continuously affecting many countries with daily rising numbers of positive cases and deaths. Researchers and pharmaceutical companies worldwide are trying their best to develop effective vaccines, drugs, therapies and immunomodulators for tackling COVID-19, few of these have reached to clinical trials and are presently being evaluated under different phases of clinical trials. However, this may take few months still to get the market and to be practically available for the end-users vaccination (Ciotti et al., 2020; Dhama et al., 2020a; Dhama et al., 2020c; Felsenstein et al., 2020; Keam et al., 2020; Keni et al., 2020; Vellingiri et al., 2020; Yatoo et al., 2020). More recently, Russia has claimed to develop the COVID-19 vaccine, and vaccines being developed by other countries (USA, UK, India, and others) are in the pipeline. Under such scenario, timely diagnosis, increasing diagnostic capabilities, contact tracing, adaptation of appropriate strict disease prevention, control and mitigation strategies including follow-ups of bio-security, personal biosafety measures with wearing face masks, frequent washing of hands with water, soap and applying hands sanitizers, social distancing, and proper disinfection, hygiene and sanitization practices, are the promising options to circumvent SARS-CoV-2 infection and limit its spread (Ahmad et al., 2020b; Chu et al., 2020; Dhama et al., 2020a; Rodriguez-Morales et al., 2020). Due to the currently increasing trends of SARS-CoV-2 spreading within many countries, and specifically massively spreading in three countries viz., the United States of America, Brazil and India, affecting others like Russia, South Africa, Mexico and various countries, COVID-19 may further be affecting many more millions along with killing millions of people if its spread is not halted shortly.

Understanding the genomic organization, molecular biology, pathogenesis, pathobiology, and immunobiology of the SARSCoV-2 in an in-depth manner with better knowledge gains will pave ways to design effective vaccine candidates and drug targets. The present review highlights a few of the salient information on this pandemic virus while mainly focusing on SARS-CoV-2 structure, genome composition, pathogenesis, pathobiology, and advances and progress being made to treat COVID-19 patients.

\section{Coronaviruses}

Coronaviruses (CoVs) are positive-sense, single-stranded RNA viruses. The RNA genome is encased by a nucleoprotein $(\mathrm{N})$ to form a helically symmetric helix. They cause various diseases in 
human and different animals, indicating their broad host range that includes livestock, companion (dogs, cats), and other domestic animals, including cows, pigs, chicken and birds (Fehr \& Perlman, 2015), which leads to significant researches on these viruses in the last 20 years. The viruses infect the hepatic, respiratory, gastrointestinal, brain and nervous systems of mammals, birds, bats, mice, and several other feral species (Ge et al., 2013; Roujian et al., 2020). A high-prevalence and wider spread nature of CoVs and their broad genetic diversity have been observed. The probability of the human-to-human and animal-to-human transmissions of the viruses might be due to the result of newly emerging coronaviruses, for which one approach needs to be adopted for effective control (Bonilla-Aldana et al., 2020; Tiwari et al., 2020).

The severe acute respiratory syndrome (SARS) was noticed in Guangdong province of China in 2002, which spread in more than 26 countries till 2003. Further, the Middle East respiratory syndrome (MERS) in Saudi Arabia in 2012 has shown the changing properties of coronaviruses for their new hosts (Roujian et al., 2020). These two diseases infect the lower respiratory tract of human, which causes death due to the failure of respiratory function. In December 2019, an epidemic in Wuhan, China, of mystery pneumonia brought widespread concern to people around the world, due to severe clinical symptoms among patients, i.e., fever, headache, dry cough, dyspnoea, and pneumonia (Zhou et al., 2020a; Zhou et al., 2020b). The mortality rate was $10 \%$ for SARS, $37 \%$ for MARS, while the mortality rate in the case of COVID-19 was $2.9 \%$ as per the initial data of China. The initial illness can be quickly identified with clinical features of a rise in the body temperature, dyspnea, pneumonia, and a significant reduction in the white blood cells count, particularly lymphocytes.
Taxonomically, coronaviruses belong to the Coronavirinae subfamily, Coronaviridae family, and order Nidovirales, which contain viruses of both medical and veterinary importance. At present, coronaviruses are categorized into four major genera, including Alphacoronavirus, Betacoronavirus, Gammacoronaviruses and Deltacoronavirus (Woo et al., 2012; de Groot et al., 2013; Tekes \& Thiel, 2016). There is currently a total of 15 known strains of CoVs within different species. Only six species cause human diseases and chronic disorders; they are human coronavirus (HCoV)-229E, HCoV-OC43, HCoV-NL63, HKU1, SARS-CoV and MERS-CoV (Fehr \& Perlman, 2015). Of the four coronavirus genera, members of the Alphacoronavirus and Betacoronavirus genera infect mammalian species (Fehr \& Perlman 2015), whereas the Gammacoronaviruses and Betacoronavirus infect birds, fish and only a few of them can infect mammals as the detail is listed in Figure 1. In some cases, human coronaviruses (such as HKU1) only create minor upper respiratory diseases in infants, small children, and the elderly, while in other cases, they may induce severe morbidity. Patients infected with MERS-CoV and SARS-CoV at the lower respiratory tract suffer severe respiratory syndrome (Su et al., 2016). Many CoVs can also affect livestock, such as bovine coronavirus of cattle, porcine epidemic diarrhoea virus (PEDV) and porcine hemagglutinating encephalomyelitis virus (PHEV) of pigs and may cause major financial losses (Simas et al., 2015). Coronaviruses could be found in other animals, including bees, bats, moose, and other wildlife (Watanabe et al., 2010; Monchatre-Leroy et al., 2017; Menachery et al., 2020). In 2016, the HKU2-related bat CoV triggered swine-acute diarrhoea in Southern China, with over 24,000 deceased piglets (Zhou et al., 2018). This was the first report of bat $\mathrm{CoV}$ spillage, causing severe animal disease (Cui et al., 2019).

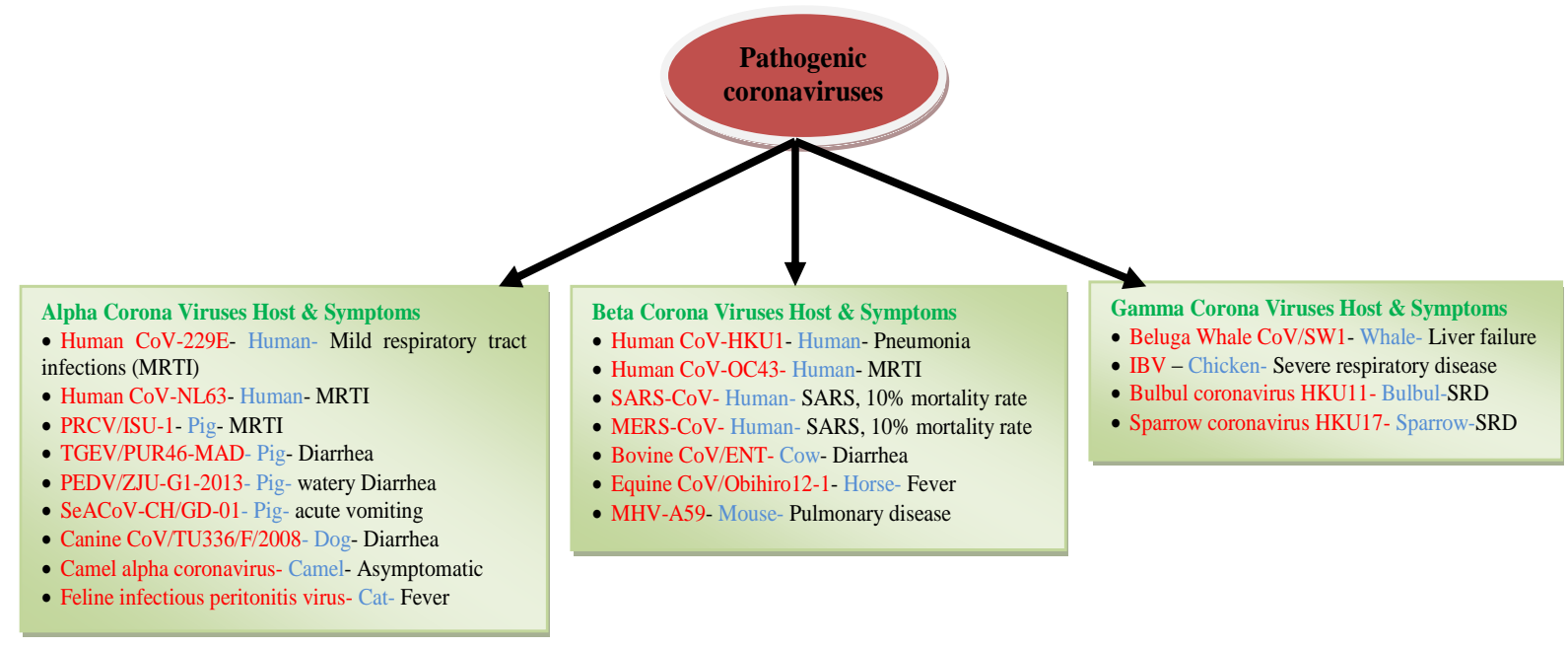

Figure 1 List of important pathogenic corona viruses their known host and symptoms (Reproduced from Chen et al., 2020e under Creative Commons Attribution (CC BY) licence, permission granted by publisher John Wiley and Sons)

Journal of Experimental Biology and Agricultural Sciences

http://www.jebas.org 


\section{SARS-CoV-2}

Reported data revealed the connection of SARS-CoV-2 infection with the Seafood Wholesale market in Wuhan, China, which has been regarded as the epicentre of the 2019-nCoV outbreak (Huang et al., 2020a; Huang et al., 2020b; Guan et al., 2020a). However, it should be noted that many other animal species are also sold at the Wuhan Seafood market. At the earliest outset of the outbreak, six clinical samples were collected from seven sellers/food delivers of the market, which was admitted to an intensive care unit in Wuhan Jin Yin-Tan Hospital with severe pneumonia (Chen et al., 2020a). The causative viruses could be isolated from five out of the six samples and later identified at the Wuhan Institute of Virology (WIV) as coronavirus. These early cases of the outbreak were from their direct contact with the seafood, but as the disease spread further, those who were not visited the Wuhan Seafood market were also infected, indicating human-to-human transmission of the virus. Metagenomic analysis of next-generation sequencing data of one of the five virus isolates (WIV04) revealed that it was only $79.60 \%$ similarity with the previously reported SARS-CoV BJ01, but $96 \%$ identity with the bat coronavirus (Zhou et al., 2020a; Zhou et al., 2020b). This genome sequence has been submitted to the Global Initiative on Sharing All Influenza Data (GISAID) accession numbers (EPIISI402127-402130) (Zhou et al., 2020a; Zhou et al., 2020b). Full-length genome sequences of the remaining four isolates (WIV03, WIV05, WIV06, and WIV07) showed more than $99.98 \%$ resemblance to each other (Zhou et al., 2020a; Zhou et al., 2020b). On $12^{\text {th }}$ January 2020, the World Health Organization (WHO) has named the causative virus as 2019-nCoV. On January $20^{\text {th }}, 2020$, it was established that the SARS-CoV-2 belongs to the genus Betacoronavirus based on genome sequence analysis of 291 isolates (Chen et al., 2020a), although they cause different clinical symptoms than the antecedent SARS and MERS. On $1^{\text {st }}$ March 2020, a total of 79,968 COVID-19 cases were recognized in mainland China with 2873 deaths. The COVID-19 becomes an epidemic in China and spread further rapidly to 27 other countries in different parts of the world due to the lack of specific preventive and therapeutic measures (Letko et al., 2020). The rapid disease transmission of human-tohuman was due to direct contact (Millet \& Whittaker, 2015; Tarar et al., 2020). Therefore, government management authorities restricted travel from Wuhan to other countries soon after. Currently, the COVID-19 has affected people across the world with severe conditions, particularly the USA, Brazil, India, Russia, and other many countries. Consequently, across the globe, the travelling restriction was imposed, social distancing was suggested, and the lockdown was implemented as an immediate control measure of the infection to all the affected countries.

While the risk of animal-to-human transmission for the 2019 n$\mathrm{CoV}$ has been noted, it was necessary to identify their natural host from the market. Also, due to several unknown features and properties of SARS-CoV-2, it is necessary to make a global awareness among the scientific societies that are not directly associated with the biological phenomena of the coronaviruses. Coronavirus is recognized to circulate in birds and mammals. Past examinations unveiled the zoonotic origin of both MERS-CoV and SARS-CoV, initially originating from bats (Guan et al., 2003; Lau et al., 2005). SARS-CoV spread from bats to palm civets to humans (Song et al., 2005), whereas bats to camels to humans is the route for MERS-CoV (Muller et al., 2014; Chu et al., 2014; Song et al., 2018). The current pandemic caused by SARS-CoV-2 is also considered to be originated from bats, based on the similarity of the genetic sequences to other coronaviruses ( $\mathrm{Li}$ et al., 2020a; Zhou et al., 2020a; Zhou et al., 2020b). However, the intermediate animal host may have played a role in transmitting SARS-CoV-2 (Lu et al., 2020a). The identity of the intermediate animal host between bat reservoir and human remains unknown. The virus data obtained from pangolins sample reveals more closeness to the SARS-CoV-2, and further investigations of mammals consumed or handled by humans can uncover more closely related viruses (Liu et al., 2019).

\section{SARS-CoV-2 structure, genome composition and salient characteristics}

Cryoelectron tomography and cryoelectron microscopy have revealed that $\mathrm{CoVs}$ are spherical with a diameter of about $125 \mathrm{~nm}$ (Neuman et al., 2006; Barcena et al., 2009). Coronaviruses are primarily distinguished by their club-shaped spike projections on the virion. Such spikes describe the virion surface morphology and give its appearance of the solar corona, which is responsible for its name "Coronavirus". The nucleocapsid/ ribonucleoprotein (RNP) of CoVs have helical symmetry that is not a typical feature of RNA viruses, although the coronaviruses have positive-sense, singlestranded RNA genomes. Initial reports of SARS-CoV-2 comparison reveal $79 \%$ similarity with SARS-CoV at the nucleotide level. However, the similarity patterns are different among genes, like the spike (S) protein of SARS-CoV-2 and SARS-CoV display only $72 \%$ similarity. The close evolutionary relationships suggest the resemblance of SARS-CoV-2 genomic structure with other beta coronaviruses in the gene order as 5'replicase ORF1ab-S-envelope (E)- membrane (M)-N-3' (Zhang et al., 2020a).

The unsegmented, positive-sense RNA genome of CoVs is approximately $30 \mathrm{~kb}$. The genome has a 5 -cap configuration and a 3'-polyadenylated (polyA) tail. The organization of the $\mathrm{CoV}$ genome is as follows: 5'-leader-UTR followed by replicase genes (ORF1a and ORF1b for polyprotein production)-ORF2 for S (spike protein)- ORF 4 for E (envelope protein)- ORF5 for M (Membrane protein)- ORF9 for N (nucleoprotein)-3' UTR-polyA tail, with additional genes scattered within the structural genes at the 3 '-one- 
third of the genome (Snijder et al., 2006; Sawicki et al., 2007). On the genome 5'- end, an untranslated region (UTR) and leader sequence comprise several loops needed for genome replication and transcription. Transcriptional Regulatory Sequences (TRSs) to be required for the gene expressions are often presented at the start of each structural or accessory gene of the virus. The 3'-UTR also includes the RNA structures necessary for viral RNA synthesis and replication. The accessory proteins are virtually unessential in tissue culture for replication, but some of them have proven to play an essential role in causing neuroinflammation. In general, CoVs produce 120 to $160 \mathrm{~nm}(27-32 \mathrm{~kb})$ particles that are the largest RNA genomes among the positive-sense, one-stranded RNA viruses as shown in Figure 2a and 2b. The diameter of the helical nucleocapsid is approximately $9-11 \mathrm{~nm}$ in size. In contrast to RNA coding for the structural, functional and accessory proteins that comprise just about $10 \mathrm{~kb}$ of the virus genome (one-third of the 3'end), the replicase genes (ORF1a and ORF1b) that encode nonstructural proteins (nsps) 1-16, take up about $20 \mathrm{~kb}$ of the genome (Chen et al., 2020a).

Usually, RNA virus mutation rates are far higher than DNA virus replication rates. However, CoVs have several enzymes that carry out RNA processing, like the $3^{\prime}-5^{\prime}$ exoribonuclease or nsp14, which can remove the incorrectly added nucleotide to the growing RNA strand. This is a unique feature of a $\mathrm{CoV}$ reverse transcription complex (RTC). Among all RNA viruses, the $3^{\prime}-5$ exoribonuclease is very inimitable to CoVs, possibly having RTC proofreading feature. Sequence analysis has demonstrated that the 2019-nCoV belonging to the genus Betacoronavirus has a standard $\mathrm{CoV}$ genomic structure and includes Bat-SARS, like Bat-SL ZXC21, (SSL)-ZC45, MERS-CoV, and SARS-CoV. The CoVs phylogenetic tree found a close resemblance of SARS-CoV-2 with bat-SL-CoV ZXC21 and farther distant to SARS-CoV (Chen et al., 2020a; Zhou et al., 2020a; Zhou et al., 2020b). Four major types of structural proteins are identified in coronavirus particles. These are the membrane $(\mathrm{M})$ protein, spike $(\mathrm{S})$ protein, Envelope $(\mathrm{E})$ protein and nucleoprotein $(\mathrm{N})$. Some coronaviruses have hemagglutininesterase as another structural protein. Genes coding for these proteins are located at the 3 '-one-third of the viral genome (Fehr \& Perlman, 2015).

\subsection{Spike (S) protein}

The $\mathrm{S}$ protein $[\sim 150 \mathrm{kDa}, 1273$ amino acids comprise a signal peptide of 1-13 amino acids located at the N-terminus, the S1 subunit (14-685 residues), and the S2 subunit (686-1273 residues] forms club-shaped homotrimeric projections on the surface of coronavirus virion (Delmas et al., 1990; Beniac et al., 2006). The trimeric $\mathrm{S}$ protein is a class I viral fusion protein (Bosch et al., 2003). Each molecule of $S$ protein encompasses three parts: a relatively large $\mathrm{N}$-glycosylated ectodomain, a single-pass transmembrane portion and a short endosegment. At the initial

(A)

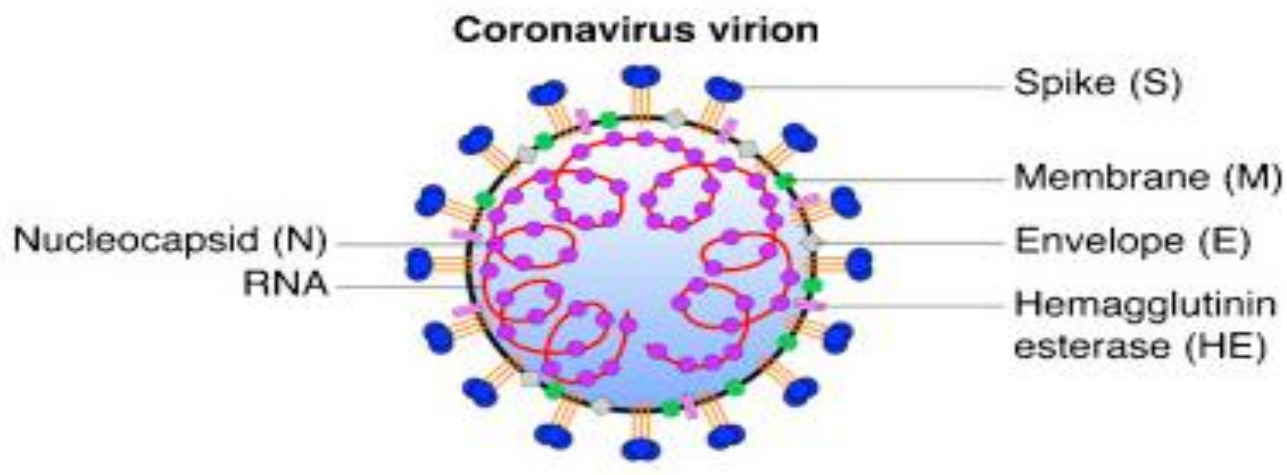

B
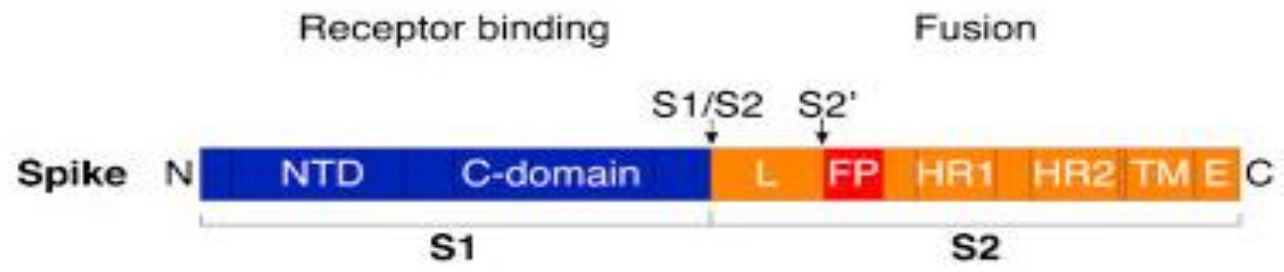

Figure 2 Showing Virion structure (A) and detail of receptor binding site (B) (Reproduced from Millet \& Whittaker, 2015 under Creative Commons Attribution (CC BY) licence, permission granted by "Elsevier")

Journal of Experimental Biology and Agricultural Sciences

http://www.jebas.org 
phase of infection, host furin-like protease cleaves $\mathrm{S}$ protein into two distinct polypeptides known as S1 and S2 subunits. The S1 contains two domains, i.e., C-terminal domain (S1-CTD) and $\mathrm{N}$ terminal domain (S1-NTD) that can serve as a receptor-binding ligand for coronaviruses, e.g., SARS-CoV uses S1-CTD to bind to human ACE2, while murine hepatitis coronavirus uses S1-NTD to interact with CEACAM1 (colon embryonic antigen cell adhesion molecule 1) (Kubo et al., 1994; Cheng et al., 2004; Li et al., 2005; Lu et al., 2013). The S1-CTD has two subdomains, namely the receptor-binding motif $(\mathrm{RBM})$ and the core structure $(\mathrm{Li}$, 2015). The RBM of the S1-CTD of SARS-CoV-2 binds to human ACE2 receptor on the membrane of host cell; thus, the S1-CTD functions as RBD of the SARS-CoV-2 (Wang et al., 2020a; Li, 2015). The heptad repeat is a repetitive heptad peptide, HPPHCPC, where $\mathrm{H}$ is hydrophobic residue, $\mathrm{P}$ is hydrophilic residue and $\mathrm{C}$ is a charged residue. Under the acidic $\mathrm{pH}$ within the endosome, the S2 acquires conformational change and inserts the FP into the endosomal membrane and together with the HR1 and HR2 bring about the fusion of the viral and endosomal membranes resulting in the viral genome released into the cytoplasm for further translation and replication (Baranov et al., 2005; Belouzard et al., 2009; Huang et al., 2020a; Huang et al., 2020b). The S protein contains major neutralizing epitopes and is the target of vaccine and therapeutic development. The S gene of SARS-CoV-2 encoding $22 \mathrm{~N}$-linked glycan sequences per promoter plays an imperative role in protein folding, and immune evasion (Watanabe et al., 2020) reported the glycan structures on a recombinant SARS-CoV2 S immunogen using the mass spectrometric method. The SARSCoV-2 S glycan was different from the host glycan and may have a high impact on vaccine design and viral pathobiology (Watanabe et al., 2020).

\subsection{Membrane (M) protein}

The M protein is a relatively small protein $(\sim 25-30 \mathrm{kDa})$ which is the main structural protein of the coronavirus virion. This protein has a tiny glycosylated $\mathrm{N}$-terminal ectodomain, three transmembrane domains and a relatively long C-terminal endodomain (de Haan et al., 1998; Nal et al., 2005). Although most of the nascent M proteins are introduced in the endoplasmic reticulum (ER) membrane by the co-translational pathway (because the nascent M-protein does not contain the signal sequence for the translation), experimental data have shown that $\mathrm{M}$ protein in the virion adopt two conformations, i.e., long $\left(\mathrm{M}_{\mathrm{LONG}}\right)$ and compact $\left(\mathrm{M}_{\mathrm{COMPACT}}\right)$, which each of them contains two copies of M protein (Neuman et al., 2011). The elongated $\mathrm{M}$ protein interacts with nucleocapsid, but the compact $\mathrm{M}$ does not (Neuman et al., 2011). Coronavirus M protein plays a key role in viral assembly, through M-M, M-nucleocapsid, and M-spike (S) interactions via the highly conserved cytoplasmic domain of the M protein (Arndt et al., 2011).

\subsection{Envelope (E) protein}

E protein of coronaviruses is a small ( 8-12 kDa; 76-109 amino acids) integral membrane protein that inserts once through the viral membrane. This small protein exhibits a $\mathrm{C}$ terminal endodomain and $\mathrm{N}$-terminal ectodomain. Although the endodomain of the $\mathrm{E}$ protein has ion channel activity but this protein is not necessary for virus proliferation. However, it is necessary for pathogenesis by interacting with the host proteins and causing the host cell stress (Nieto-Torres et al., 2011). E protein is a chaperone that facilitates interactions between $\mathrm{M}$ protein monomers (Boscarino et al., 2008).

\subsection{Nucleoprotein $(\mathrm{N})$}

Coronavirus $\mathrm{N}$ is a phosphoprotein that encapsidates the viral RNA forming nucleocapsid. $\mathrm{N}$ protein consists of two distinct domains, an N-terminal domain (NTD) and the C-terminal domain (CTD), which binds RNA in vitro. $\mathrm{N}$ protein has been proposed to cause a shift in structure to improve the virus resistance to nonvirative RNA with specific mechanisms for binding RNA and phosphorylation process. In beads-to-string confirmation, $\mathrm{N}$ protein binds specifically to the viral genome. Two different RNA substrates of the $\mathrm{N}$ protein have been recognized including Translation Regulatory Sequences (TRSs) and the RNA Packaging signal (Ps) which is located at the 69nucleotide (nt) stem-loop structure at the 3'-end of ORF1b (Molenkamp \& Spaan, 1997). The $\mathrm{N}$ protein uses the N3 domain in the C-terminal to bind to the Ps; this N3 also interacts with the M protein (Kuo \& Masters, 2013). N protein also binds to nsp3, the main component [papain-like protease of the replication complex (ORF1a and ORF1b)] and the M protein (Hurst et al., 2009; Hurst et al., 2013; Nikhra. 2020). Such protein interactions are effective to link the virus genome to the reverse transcription complex (RTC), and ultimately compress the enclosed genome into the viral proteins, as shown in Figure 3a and $3 \mathbf{b}$.

\subsection{Hemagglutinin-esterase (HE)}

Hemagglutinin-esterase (HE) is a fourth structural protein that forms short dimeric spike on the virion surface in some members of the genus Betacoronavirus. The protein has both receptor binding and receptor destroying activities. HE de-O-acetylates $\mathrm{N}$ acetyl-4-O-acetylneuraminic acid, probably for preventing selfaggregation and help the virus spread through mucus (Cornelissen et al., 1997). HE of the murine hepatitis virus (MHV) encourages neuro-virulence of the virus (Kazi et al., 2005), although explanations for this process is unclear (Lissenberg et al., 2005). The roles of non-structural proteins (nsp1-16) of CoVs have been reviewed elsewhere (Yoshimoto, 2020). 


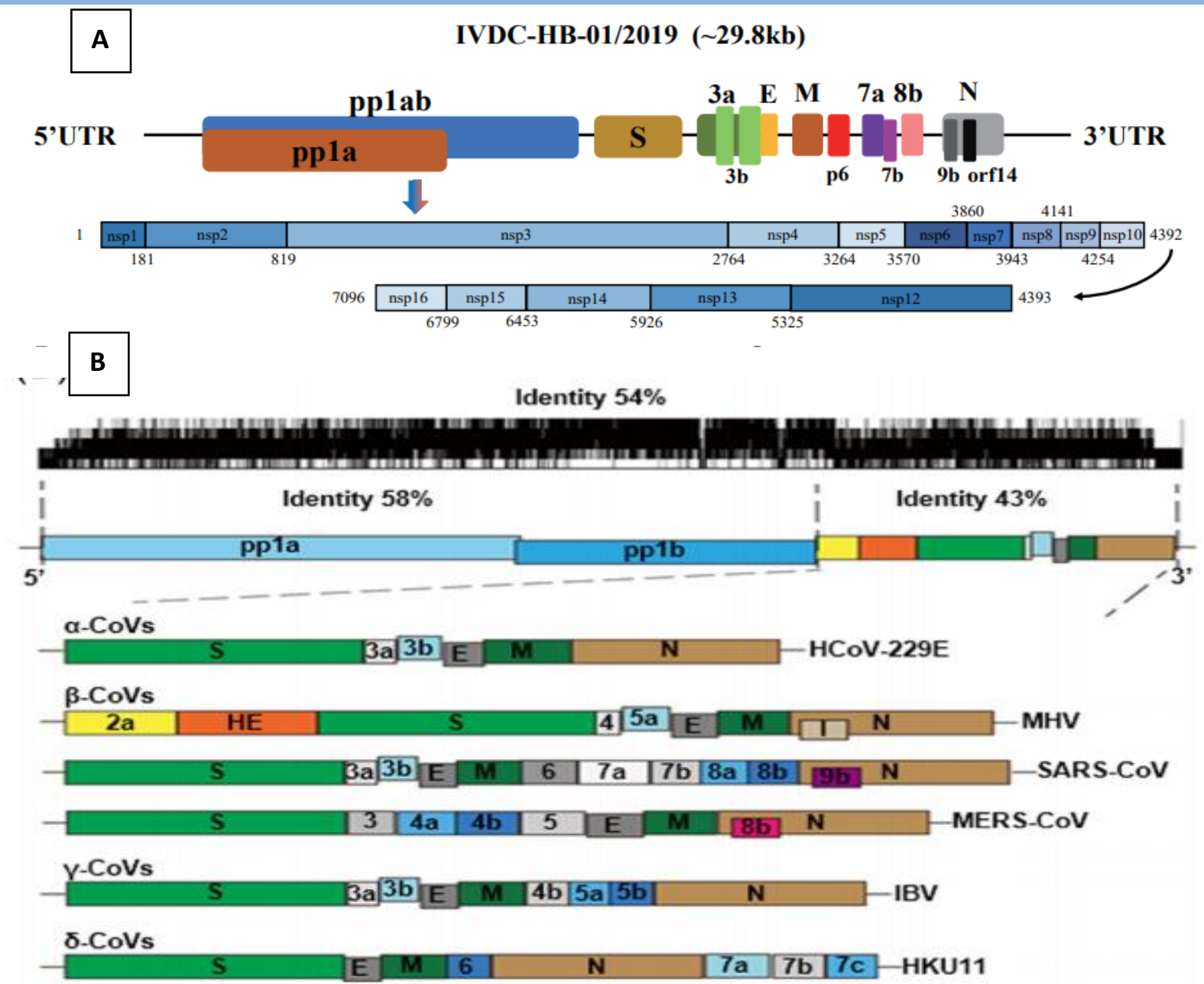

Figure 3 (A) Schematic diagram of the genome organisation and the encoded protein of pp, ab and pp;a for 1VDC HB01 (2019) starinnamely the ORF; ab, encodes the pp; ab protein that contain (15 nsps and nsp12-nsp16) (B) The genome structure of four genera of corona viruses. Pp1a and pplb represent the two long polypeptides that are processed into 16 non-structural proteins. S, E, M, and N indicate the four structural proteins spike, envelope, membrane, and nucleocapsid. 2019-nCoV, 2019 novel coronavirus; CoVs, coronavirus; HE, hemagglutinin-esterase (Reproduced from Chen et al., 2020e under Creative Commons Attribution (CC BY) licence, permission granted by publisher John Wiley and Sons)

5 Association of pneumonia outbreak with new coronavirus of probable bat origin in China

The SARS-CoV-2 has six essential open reading frames (ORFs), and a variety of additional genes, which is a common characteristic of CoVs. The nucleotide sequence of SARS-CoV was shared by $79.60 \%$ only with that of SARS-CoV-2. Nevertheless, the aminoacid sequence of the seven conserved replicate domains in ORF1ab for characterization study showed $94.4 \%$ similarity between 2019 $\mathrm{n} \mathrm{CoV}$ and SARS-CoV, which was given strong evidence for closed species similarity. Further disclosed for the short-region of RNA-dependent RNA polymerase (RdRp) of bat coronavirus (BatCoV RaTG13) presented a high sequence identity with SARSCoV-2. Subsequently, the full-length sequence analysis of the
SARS-CoV-2 RNA sample showed more close relations with the bat coronavirus (Bat CoVRaTG13). In addition, the Simplot analysis showed that the entire SARS-CoV-2 genome is highly like RaTG13, with $96.2 \%$ similarity of the genome sequence. No proof of recombination events in SARS-CoV-2 has been recognized on the related genome sequences of SARS-CoV-2, i.e., RaTG13, SARS-CoV, and previously mentioned bat SARSr-CoV (Zhou et al., 2020a; Zhou et al., 2020b). Furthermore, phylogenetic analysis of RdRp, S protein, full-length genomes and gene sequences have also shown that RaTG13 is the closest relative to SARS-CoV-2 for all sequences and that they are distinguished from other SARSCoVs by phylogenetic analysis information and serological sample test (Zhou et al., 2020a; Zhou et al., 2020b). Molecular and serological analyses of the specific patient continuum given 
evidence of strongly differentiated S-encoded receptor-assembly protein, based on molecular and serological evidence, with a similarity of less than $75 \%$ of the nucleotide sequence to other previously identified SARS-CoVs, with $93.1 \%$ nucleotide identification (Letko et al., 2020). The S genes (ORF2) of RaTG13 and SARS-CoV-2 were longer than other SARS-CoVs. Most differences in the S-gene sequence from SARS-CoV-2 in contrast to SARS-CoV sequence based on analytical data from infected cells have shown the three short insertions into the $\mathrm{N}$-terminal domain and changes in four out of five major receptor-binding residues. The close phylogenetic relationship with RaTG13 indicates that SARS-CoV-2 could have come from bats (Zhou et al., 2020a; Zhou et al., 2020b). The Comparative genome structures of four genera of coronaviruses have been shown in Figure 4.

\section{Coronavirus infection process}

Interaction between the $S$ protein and its receptor results in initial virion binding to the host cell followed by endocytosis of the virion. The sites in the $\mathrm{S} 1$ segment of the coronavirus S protein for receptor binding, i.e., receptor-binding domain (RBD), depend on the host species and the virus strains. The $\mathrm{S}$ protein must be cleaved by the host proteases, furin and TMPRSS2, at a prerequisite $\mathrm{S} 1 / \mathrm{S} 2$ and $\mathrm{S} 2{ }^{\prime}$ sites under an acidic $\mathrm{pH}$ within endosome to expose a fusion peptide (FP) that together with the HR1 and
HR2 form pore on the endosomal membrane through which the virus genome exits into the cytosol for replication (Millet \& Whitaker, 2015; Nikhra, 2020). The S protein-host receptor interaction and the virus tissue tropism are the primary determinants for a $\mathrm{CoV}$ infection of a particular host species. At the initial phase of infection, the S protein, which is an integral membrane protein on the SARS-CoV-2 surface binds to ACE2. ACE2 is a carboxypeptidase, which is divided into angiotensin's I and II. The enzyme is normally found on the surface of cells as an ectoenzyme. The ACE2 is a zinc metalloprotease of the ACE family. The human ACE2 sequence consists of an external glycosylated N-terminal, a transmembrane portion, and a small cytoplasmic tail. It is abundant in nasal, oral and nasopharyngeal mucosae, lungs and alveolar epithelial cells as well as on the arterial and venous endothelial cells of humans and other animals. ACE2 has been involved in causing vasculitis, deranged immune function, lung inflammation and widespread alveolar disruption with serious clinical symptoms of hyaline membrane formation during the SARS-CoV-2 infection (Giacca et al., 2020). This makes the oral cavity a high-risk pathway for infection with SARS-CoV-2 Within the cytoplasm, the viral positive-sense RNA translates into two polyproteins: ppla and pplab (Brierley et al., 1989), which are processed into non-structural proteins by the viral proteases forming a replication-transcription complex (RTC) of double-membrane vesicles (Araki et al., 2010). The RTC produces

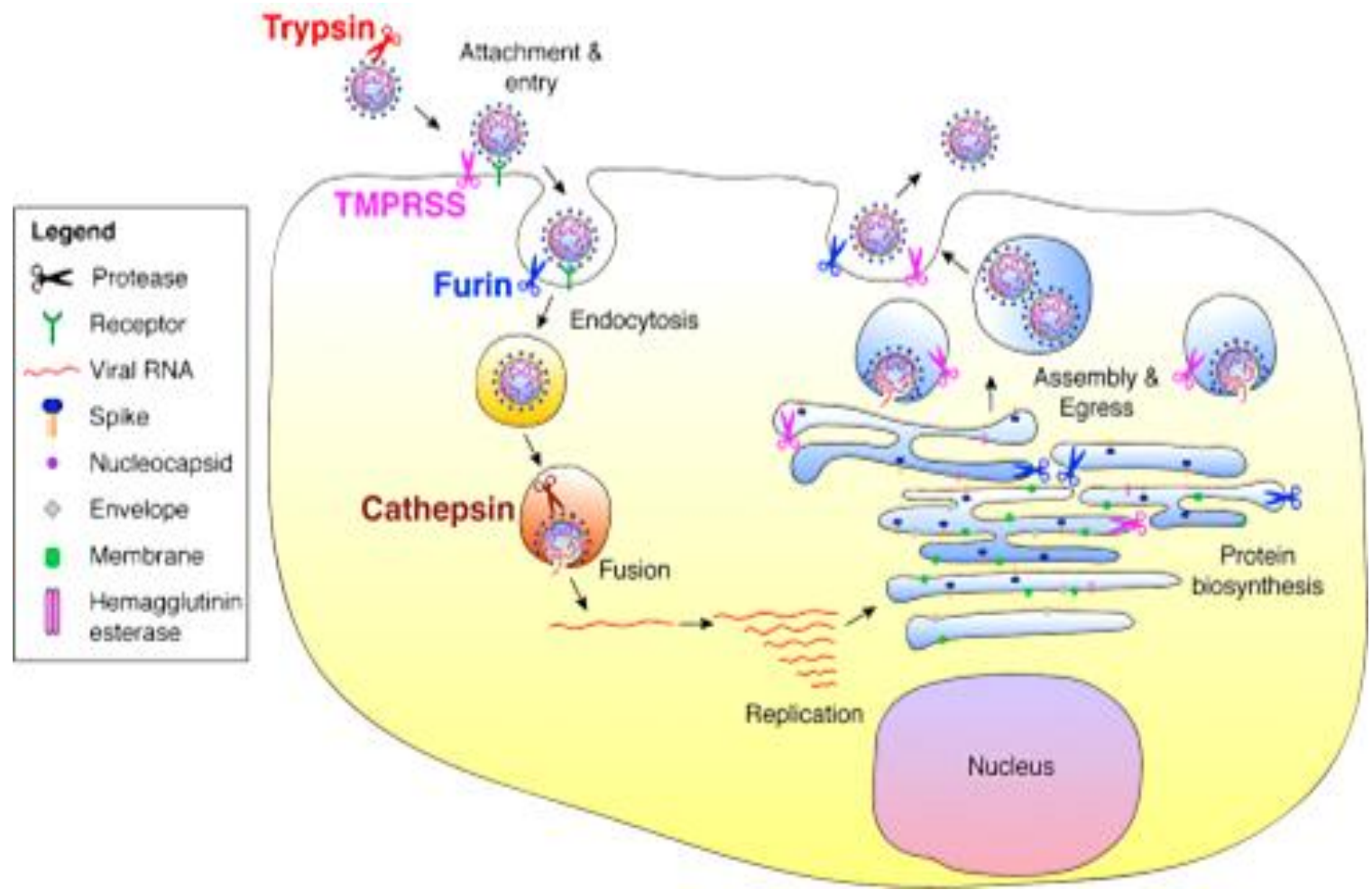

Figure 4 Pathogenesis process of virus 2019-nCoV and release of new virion through replication process (Reproduced from Millet \& Whittaker, 2015 under Creative Commons Attribution (CC BY) licence, permission granted by "Elsevier")

Journal of Experimental Biology and Agricultural Sciences http://www.jebas.org 
a nested set of sub-genomic RNAs encoding structural and accessory proteins (Ziebuhr et al., 2000). By manipulating the ER and Golgi complex (Mielech et al., 2014), the newly synthesized genomic RNA and four structural proteins are assembled forming viral particle, which egresses from cells by budding (the plasma membrane fuses the virion-containing vesicles to free the virus progeny). The whole mechanism of the infection process of corona virus-host cell has been shown in Figure 5.

Interaction between SARS-CoV-2 Spike (S) glycoprotein and $\mathrm{ACE}_{2}$ is a crucial step for the introduction of the virus into the host cell. Extensive analysis using various methods is underway to the binding affinity of coronaviruses to host receptors. Structural identification of the Betacoronavirus receptors revealed that human cells that express $\mathrm{ACE}_{2}$ were bound by SARS-CoV and SARS-CoV-2 (Snijder et al., 2003), but not human dipeptidyl peptidase-4 (DPP4) (receptor for MERS-CoV), or aminopeptidase $\mathrm{N}$ (APN, CD13) (receptor for human respiratory coronavirus $\mathrm{HCV}-229 \mathrm{E})$. The binding affinity of the S protein of SARS-CoV-2 to $\mathrm{ACE}_{2}$ is $10-20$ times greater than SARS-CoV, which has been shown in the SARS-CoV-2 spike cryo-EM structure confirmation. TMPRSS2 and cathepsin cause the cleavage of the trimeric $S$ protein of SARS-CoV at the cell surface (Brown et al., 2007; Guan et al., 2011). The cryo-electron microscopic analysis of the SARSCoV-2 S protein shows that RBD like in other coronaviruses undergoes a hinge-like movement for the "up" and "down" conformations. ACE2 receptor interacts with RBD only when it is in up confirmation. The epitope on CR 3022 binds to RBD even when RBD is present in up conformation (Yuan et al., 2020).

\section{Clinical symptoms of COVID-19}

Clinical indications of COVID-19 appear after SARS-CoV-2 infection of 2 to 14 days. The typical manifestations of COVID-19 patients include dry cough, fever, headache, difficulties in breathing (dyspnea), and pneumonia (Bilal et al., 2020a; Bilal et al., 2020b; Shah et al., 2020). In the onset of the disease, computerized chest tomography imagery, and progression of respiratory failure through alveolar injury lead to death. The latest research by 1099 studies has reported that fever (88.7\%), cough (67.8\%), tiredness (38.1\%), sputum development (33.4\%), shortness of breath $(18.6 \%)$, headache $(13.6 \%)$ and sore throat (13.9\%) are typical clinical manifestations (Guan et al., 2020a). In addition, a number of patients showed gastrointestinal (GI) symptoms, including vomiting $(5.0 \%)$ and diarrhoea (3.8\%). Clinical studies from the Hubei province of China have demonstrated consistent symptoms as described with previous estimates of 41, 99, and 138 cases the detail has been listed in Figure 6 (Assiri et al., 2013; Chen et al., 2020a). The predominant symptoms were fever and cough, while rare upper respiratory and
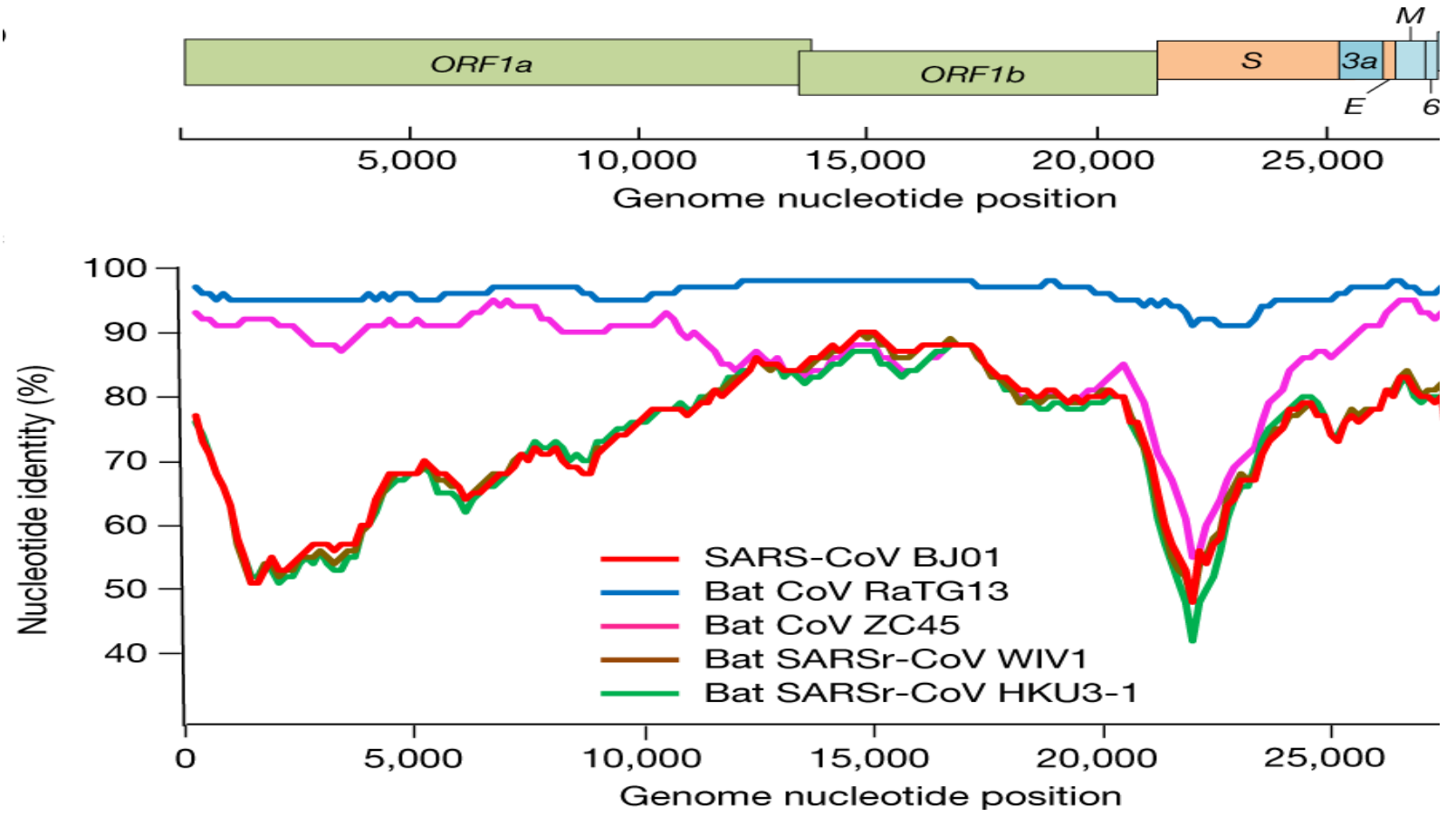

Figure 5 Genomic organization of 2019-nCoV WIV04. M, membrane. Similarity plot based on the full-length genome sequence of 2019nCoV WIV04. Full-length genome sequences of SARS-CoVBJ01, bat SARSr-CoV WIV1, bat corona virus RaTG13 and ZC45 were used as reference sequences (Reproduced from Zhou et al., 2020b under Creative Commons Attribution (CC BY) licence, permission granted by Creative Commons License Deed) 
GI symptoms indicated differences in viral tropism as opposed to MERS-CoV, SARS-CoV, and influenza virus.

Elderly and persons underlying with any disorders and comorbidities (i.e., diabetes, chronic pulmonary disease, hypertension, and cardiovascular disease) are prone to septic shock, metabolic acidosis, acute respiratory distress syndrome (ARDS), and coagulation dysfunction, which lead to the death due to increased severity of COVID-19 (Apicella et al., 2020; Baradaran et al., 2020; Huang et al., 2020a; Huang et al., 2020b; $\mathrm{Lu}$ et al., 2020b). In the laboratory analysis, the majority of patients showed normal or reduced white blood cell numbers and lymphocytopenia. The D-dimer level, neutrophil count, creatinine, and blood urea levels were, however, higher in the seriously ill patients and the counts of lymphocytes were further reduced. ICU patients were presenting elevated plasma levels of IL-2, IL-7, IL10 , granulocyte colony-stimulating factor (G-CSF), macrophage inflammatory protein 1- $\alpha$ (MIP1a), interferon gamma-induced protein 10 (IP-10; also known as C-X-C motif chemokine ligand 10 or small-inducible cytokine B10), monocyte chemoattractant protein-1 (MCP-1), and tumor necrosis factor $\alpha$ (TNF- $\alpha$ ) (Huang et al., 2020a; Huang et al., 2020b).

Neurological manifestations have also been documented in some COVID-19 patients comprising of weakness, hyposmia, headaches, encephalitis, altered consciousness, neuropathy, demyelination, and stroke (Montalvan et al., 2020). COVID-19 has also been implicated in affecting kidneys leading to chronic kidney disease and acute kidney injury in critically ill patients. The SARS-CoV-2 can damage kidneys through direct tropism and indirectly via cytokine storm and other pathogenic modes of action causing higher fatality (Gabarre et al., 2020; Henry et al., 2020; Patel et al., 2020a; Ronco \& Reis, 2020).

\section{Advances in treatment, developing drugs and therapies}

The vast spreading potential of COVID 19 amidst the scarcity of knowledge of biological properties of the virus along with its precise treatment approach has led to an array of therapeutic regimens been followed in different countries. Several exploratory clinical trials with many recognized drugs are also being carried out in various parts of the world. However, in the current scenario, timely diagnosis, isolation, hospitalization of patients confirmed with SARS-CoV-2 infection along with supportive care, like supplemental oxygen and fluid therapy, proper ventilation antibiotic therapy to manage secondary bacterial infections is being carried out ( $\mathrm{Li}$ et al. 2020b; Guan et al., 2020b). Personal biosafety, protection, and appropriate hygiene, sanitation and disinfectants at community levels play a supporting and pivotal role in containment and prevention of the disease (Shahbaz et al., 2020a; Shahbaz et al., 2020b). With a lack of specific target drug against COVID-19, drug repurposing or repositioning is the immediate methodology which can be used and is being used in various laboratory and clinical trials (Altay et al., 2020). Few of the repurposed drugs and medicines have aided the treatment of COVID-19 patients, and advanced drug discovery via large-scale compound repurposing (Laura et al., 2020). Antiviral with a different mechanism of action such as RNA dependent RNA polymerase inhibition (Remdesivir, favipiravir, ribavirin), neuraminidase inhibitors (oseltamivir), nucleoside analog (Favipiravir, Remdesivir, EIDD-2801), viral fusion inhibitors (umifenovir/arbidol), protease inhibitors (lopinavir/ritonavir), systemic anti-inflammatory drugs (dexamethasone) and inhalant corticosteroids (ciclesonide), immunomodulators (anakinra, tocilizumab, sarilumab, ruxolitinib), anti-malarial medicines (chloroquine and hydroxychloroquine), anti-coagulants (heparin),

\begin{tabular}{|c|c|c|c|c|}
\hline Demography & $\begin{array}{l}\text { Date } \\
\text { Location } \\
\text { Age } \\
\text { Sex ratio } \\
\text { Mortality }\end{array}$ & $\begin{array}{l}\text { December } 2019 \\
\text { Wuhan, China } \\
49(21-76) \\
2: 7: 1 \\
25+(2.9 \%)\end{array}$ & $\begin{array}{l}\text { June, } 2012 \\
\text { Jeddah, Saudi Arabia } \\
56(14-94) \\
3: 3: 1 \\
858(37 \%)\end{array}$ & $\begin{array}{l}\text { November, } 2002 \\
\text { Guangdong, China } \\
39.9(1-91) \\
1: 1: 25 \\
744(10 \%)\end{array}$ \\
\hline \multicolumn{2}{|l|}{ Viruses } & 2019-n CoV & MERS-CoV & SARS-CoV \\
\hline Symptoms & $\begin{array}{l}\text { Fever } \\
\text { Dry-Cough } \\
\text { Dyspnoea } \\
\text { Diarrhea } \\
\text { Sore Throat } \\
\text { Ventilator }\end{array}$ & $\begin{array}{l}40(98 \%) \\
31(76 \%) \\
22(55 \%) \\
1(3 \%) \\
0 \\
9-8 \%\end{array}$ & $\begin{array}{c}98 \% \\
47 \% \\
72 \% \\
26 \% \\
21 \% \\
80 \%\end{array}$ & $\begin{array}{l}99-100 \% \\
29-75 \\
40-42 \% \\
20-25 \% \\
13-25 \% \\
14-20 \%\end{array}$ \\
\hline
\end{tabular}

Figure 6 Characterisation of patient who have been infected with 2019-n CoV, MERS-CoV and SARS-CoV (Reproduced from Wang et al., 2020d under Creative Commons Attribution (CC BY) licence, permission granted by publisher Elsevier) 
anti-fibrotic drugs (tyrosine kinase inhibitors), anthelmintic (ivermectin, niclosamide), emetine is effective in varying proportions in curing COVID-19 patients (Rizwan et al., 2020; Bilal \& Iqbal, 2020; Dhama et al., 2020a; Keni et al., 2020; Lu, 2020; Meo et al., 2020; Vellingiri et al., 2020).

Previously, various antiviral medications and systemic corticosteroid treatments, including neuraminidase inhibitors (peramivir, oseltamivir, zanamivir, etc.), ribavirin, acyclovir, and ganciclovir, as well as methylprednisolone have been applied in clinical practice for influenza virus, but these were not found effective against COVID-19 (Wang et al., 2020b; Li et al. 2020c). Remdesivir (GS-5734) is a 1'-cyano-replaced nuclear adenosine analogue, which has been found to possess large-scale antiviral activities against many RNA viruses. On the evidence basis from the mouse and cell line studies, Remdesivir could interact with the NSP12 RNA-dependent RNA polymerase (RdRp) even though ExoN re-reading operation has been intact (Agostini et al., 2020). In vitro inhibition of SARS-CoV-2 virus replication was seen using Vero E6 cells (Wang et al., 2020b). The first COVID-19 case in the USA was confirmed to be handled successfully with Remdesivir (Holshue et al., 2020). A new drug, EIDD-2801, a ribonucleotide analog, was tested for its in vitro efficiency against SARS-CoV-2 with encouraging results with the added advantage of its effectiveness against Remdesivir resistant virus (Sheahan et al., 2020). Carolacton is an inhibitor of MTHFDI which is a functional enzyme of the host with purine synthesis as one of the functions which are an important activity for viral replication has been explored as an antiviral agent for SARS-CoV-2 (Anderson et al., 2020).

The antiviral activity of anthelmintic drug niclosamide has been well documented against MERS-CoV and SARS-CoV (Xu et al., 2020a). It has been demonstrated as a potent antiviral against SARS-CoV-2 in in-vitro studies (Jeon et al., 2020). Inhibition of SKP2 activity resulting in enhancement of autophagy and reduction in virus multiplication as shown in the case of MERS$\mathrm{CoV}$ as a mode of action involved (Gassen et al., 2019) and a similar mechanism could be attributed to niclosamide in anti-viral activity against SARS CoV-2. In vitro effectiveness of Ivermectin, another anthelmintic drug against SARS CoV-2 has also been shown in experimental settings (Caly et al., 2020)

Hydroxy-chloroquine as a drug has been used with success on a large scale as an immediate remedy to treat the COVID-19 (Gao et al., 2020; Guy et al., 2020; Liu et al., 2020a). Chloroquine and hydroxychloroquine have been used for several years to combat malaria with an unexplained anti-viral action. The $\mathrm{pH}$-dependent genome release/uncoating processes of some endocytosed viruses may be inhibited by chloroquine with strong effects on SARS-CoV infection (Savarino et al., 2003). Chloroquines also have been found as immuno-modulative effects in the patient by inhibiting TNF- $\alpha$ and IL-6 production (Jang et al., 2006). It also acts as a new generation of inhibitors of autophagy by reducing autophagic flux and inhibition of autophagosome-lysosome fusion (Zhang et al., 2019). Several experiments have shown that chloroquine has interacted with cellular glycosylation of the SARS-CoV receptors and acted in VeroE6 cells both at entries and after entry stages of COVID-19 (Savarino et al., 2006). The anti-thrombotic effect of hydroxychloroquine might help prevent the micro-thrombi formation as seen in SARS-CoV-2 infection (Tang et al., 2020). With various mechanisms of antiviral actions seen in other viruses (Devaux et al., 2020), the preventive and therapeutic potential of chloroquine and hydroxy-chloroquine against SARS-CoV-2 needs to be cautiously and optimistically extrapolated and confirmed. Some combination therapies with synergistic actions have been widely reported in various clinical trials by many workers. Nucleoside analog-like Remdesivir has been used in combination with interferon and chloroquine in in-vitro experiments against COVID-19 with success (Choy et al., 2020). Some virus directed drugs such as nelfinavir in combination with host-directed drugs such as emetine, salinomycin, obatoclax and homoharringtonine were also found to act synergistically against COVID-19 (Ianevski et al., 2020).

Scientists have already reported the ability to boost the result of SARS-CoV and MERS-CoV patients with ritonavir and lopinavir (protease inhibitors), used in the treatment of human immunodeficiency virus infection (Qamar et al., 2020). In Korea, there has been a substantial decrease in the viral loads of $\beta$ coronavirus of COVID- 19 patients, as recorded in lopinavir/ritonavir combination treatments (Guo et al., 2020). It is a potent CYP3A4 and 3CLpro inhibitor of SARS-CoV in vitro that could block the main protease of virus and block its replication, and this protease appears to be highly conserved in SARS-CoV-2.

Many studies have implicated cytokine storm to cure severe clinical manifestations of COVID 19 cases. Administration of corticosteroids has been found useful in the treatment of COVID19 patients (COVID-19) (Lei et al., 2020; Patel et al., 2020b). Recently, dexamethasone, a well-known life-saving drug, has been claimed to be the world's first proven treatment to alleviate the risks of deaths in severely ill hospitalized COVID-19 patients who are particularly severely affected and need ventilation and oxygen support. The anti-inflammatory action of dexamethasone could counter the cytokine storm during COVID-19 and protect lung damage (Ledford, 2020; Patel et al., 2020b). Monoclonal antibodies against important inflammatory mediators, such as interferon-gamma, IL-1, IL-6, and complement factor 5a have been evaluated against the damaging organ effect of SARS CoV-2. The increase in pro-inflammatory cytokine IL- 6 was targeted by using IL-6 blocking antibody tocilizumab or sarilumab, which appears to 
be an effective therapeutic option (Fu et al., 2020; Xu et al., 2020b). A limited case series of 3 patients and an in-vitro study also showed the efficacy of inhalant corticosteroid (ciclesonide) in reducing virus replication and pulmonary inflammation while having the lower side effect of immunosuppression as seen in systemic corticosteroid therapy (Iwabuchi et al., 2020). This drug has a proven action as an anti-inflammatory agent along with action on its molecular target NSP15, a viral endo-ribonuclease. This approach of treatment of COVID-19 needs further exploration (Halpin et al., 2020; Lipworth et al., 2020). CRISPR based antiviral therapies have also been designed against SARS-CoV-2 for advancing hospital medicine (Abott et al., 2020; McCarthy, 2020). Artificial intelligence (AI) has also been exploited to fight against COVID-19 (Ahuja et al., 2020). Advances in cheminformatics, bioinformatics, structure-guided drug designing, network-assisted tools for analysing drug-target interactions could help in developing antiviral drugs to counter COVID-19 (Huang et al., 2020c; Omolo et al., 2020).

Alternative approaches such as antibody-based immunotherapies are being studied including the use of convalescent plasma-derived hyperimmune globulin, neutralizing antibodies, intravenous immunoglobulins, natural killer (NK) cell therapy and monoclonal antibodies targeting SARS-CoV-2 (Dhama et al., 2020c; Duan et al., 2020; Chen et al., 2020b; Market et al., 2020; Shen et al., 2020). Their therapeutic potential is also being explored to tackle SARS-CoV-2 infected patients (Market et al., 2020; Casadevall \& Pirofski, 2020; Keam et al., 2020; Kumar et al., 2020; Shanmugaraj et al., 2020; Sharun et al., 2020). Some new human antibodies such as B38, H4, 47D11 with excellent neutralizing results against SARS-CoV-2 have been identified (Jahanshahlu \& Rezaei, 2020). B38 and $\mathrm{H} 4$ have got complete binding to RBD of specifically SARS-CoV-2 thus are excellent competitive binder to ACE2 (Wu et al., 2020). Human derived 47D11 antibody potently inhibits the SARS-CoV-2 virus infection of Vero cells through some unknown mechanism (Wang et al., 2020c). Recently, the potential of donor-derived and SARS-CoV-2 specific $\mathrm{T}$ cell infusion has been explored as a potential immunotherapy modality against COVID-19 (Bachanova et al., 2020; Braun et al., 2020; Melgaço et al., 2020). HLA-E restricted CD8 T cells might improve T-cell immunotherapy in COVID-19 patients by killing infected cells and inhibiting intracellular infections, along with reducing the important component of COVID-19 pathogenesis, such as the collateral tissue damage and inflammatory response (Caccamo et al., 2020).

Harnessing the potential of innate immunity of the body's defense system along with exploiting a variety of immunomodulatory and immune-boosting agents have shown promising effects to enhance immunity and safeguard health from SARS-CoV-2 infection by aiding to eliminate SARS-CoV-2 and protect from COVID-19 disease development, and as have been used against several other pathogenic microbes (Dhama et al., 2015; Golonka et al., 2020; Gupta, 2020; Jayawardena et al., 2020; Tiwari et al., 2018; Zhong et al., 2020). Non-specific immunomodulation by various agents is in exploratory stages of clinical trials. Boosting of innate immunity by the administration of the Bacillus Calmette-Guérin (BCG) vaccine, related to the up-regulation of IL-1 $\beta$ was seen (Arts et al., 2018; Moorlag et al., 2019) in previous experiments. Non-specific immunostimulants such as beta $(\beta)$-glucans and IFNs also needs further investigations in combating against SARS-CoV-2 (Netea et al., 2020; Schijns \& Lavelle, 2020). Various workers have explored stem cell therapy with an immunomodulatory effect by affecting the secretion of many cytokines by paracrine mode or by directly interacting with immune cells. The therapeutic potential of adipose-derived mesenchymal stem cells (Rogers et al., 2020) intravenously infused human umbilical cord Wharton's jellyderived mesenchymal stem cells (Liang et al., 2020; Zhang et al., 2020b), allogenic human dental pulp stem cell (Ye et al., 2020) has been extensively explored in clinical trials and have shown promising results especially for the reduction of cytokine storm and in alleviating pneumonic symptoms in COVID-19 patients.

Dietary consumption of balanced nutritious foods along with supplementing probiotics, nutraceuticals, minerals, and vitamins have been recommended to boost up the body's immunity to fight against SARS-CoV-2 infection like other viral diseases (Wu et al., 2019; Chen et al., 2020c; Galanakis, 2020; Infusino et al., 2020; Jaggers et al., 2020; Morais et al., 2020; Sanders et al., 2020; Vellingiri et al., 2020). Zinc and vitamins (A, C, D, E, B6, and B12) have shown to boost immunity to fight virus infection, including SARS-CoV-2). Plant-derived biomolecules, plant extracts, herbs, phytochemicals, traditional medicines, Chinese medicines, Ayurvedic medicines and products are under demand for their potent immunomodulatory, antioxidant, antimicrobial including antiviral activities under the present COVID-19 era (Dhama et al., 2018; Tiwari et al., 2018; Gangal et al., 2020; Jahan \& Onay 2020; Li et al., 2020d; Prasad et al. 2020; Rastogi et al., 2020; Vellingiri et al., 2020). Several Chinese traditional medicines with in-vivo and in-vitro proven efficacy against SARSCoV-2 are Lianhuaqingwen (composed of 13 herbs), Qing Fei Pai Du Tang (a herbal formulation), Qiwei decoction, ToujieQuwen granules, ShufengJiedu capsules, Lianhua Qingwen capsules and granules, XuanfeiZhisou mixture, Shuanghuanglian oral liquids, Yupingfeng granules to name a few (Li et al., 2020a; Runfeng et al., 2020; Xiong et al., 2020). Homoharringtonine (omacetaxine), a natural product extracted from the Cephalotaxus Harrington, a tetrahydroisoquinoline alkaloid (emetine) isolated from the plant Psychotria ipecacuanha, and a bisbenzylisoquinoline alkaloid (cepharanthine) obtained from the plant Stephania cephalantha, (Choy et al., 2020; Rogosnitzky et al., 2020) are efficacious against SARS-CoV-2 in in-vitro experiments. 
Apart from all these discussed drugs, medicines and therapies, regular daily exercises, physical activities, and yogic activities also help to activate and maintain various biological functions of the body, healthy vital organs and enhance the immunity of the body to protect from lethal effects of SARS-CoV-2 infection. Since no effective vaccines or drugs are available yet, then boosting of the immunity following an overall holistic vision supported with various health approaches while with their synergistic effects, would aid in avoiding the illness, rendering potential cure and safeguarding the health during this ongoing pandemic, and reducing the mortality rate due to COVID-19 have been shown in Figure7 (Dhama et al., 2015; Tiwari et al., 2018; Golonka et al., 2020; Gupta, 2020; Vellingiri et al., 2020; Zhong et al., 2020).

Progress in COVID-19 vaccine development comprises of candidates like mRNA, DNA, vectored, virus-like particles (VLPs), inactivated/killed and attenuated SARS-CoV-2 vaccines (Sethna et al., 1991; Dhama et al., 2020a; Dhama et al., 2020c Prompetchara et al., 2020; Yatoo et al., 2020).

\section{Factors influencing the severity of SARS-CoV-2 infection} (COVID-19)

Based on mortality reports on the COVID-19, it has been concluded that the disease progressed towards a higher severity and fatality outcomes in patients due to risk factors such as older age, smoking background and in patients with pre-existing diseases and illnesses, co-morbidities such as cardiac diseases (Liu et al., 2020b), elevated blood pressure and hypertension (Chen et al., 2020d), diabetes mellitus (Apicella et al., 2020; Chen et al., 2020d), chronic lung, kidney and liver diseases, cancers, cerebrovascular diseases and other conditions like over-weight and obesity, via modulation of the virus-host interactions, affecting immunity, delay in virus clearance and other mechanisms leading to increased mortality in COVID-19 patients (Adamo et al., 2020; Arumugam et al., 2020; Baradaran et al., 2020; Liu et al., 2020b; Lu et al., 2020b; Qiu et al., 2020; Wang et al., 2020d; Wang et al., 2020e; Weis et al., 2020; Yang et al., 2020). About 481 patients who died in Italy as a consequence of SARS-CoV-2 infection have been confirmed by the Italian Institute of Health for the old age, smoking, and other chronic diseases.

Recent reports have also shown that cytokine storm syndrome was an important factor of death for a significant number of COVID-19 patients (Guo et al., 2020; Mehta et al., 2020). It is an uncontrolled release of pro-inflammatory cytokines (Tisoncik et al., 2012), which is due to a highly damaged immune system that contributes to a series of damaging mechanisms throughout the body and may end in death. This is known as hypercytokinemia. Many studies have also shown that long-range exposures to nitrogen dioxide

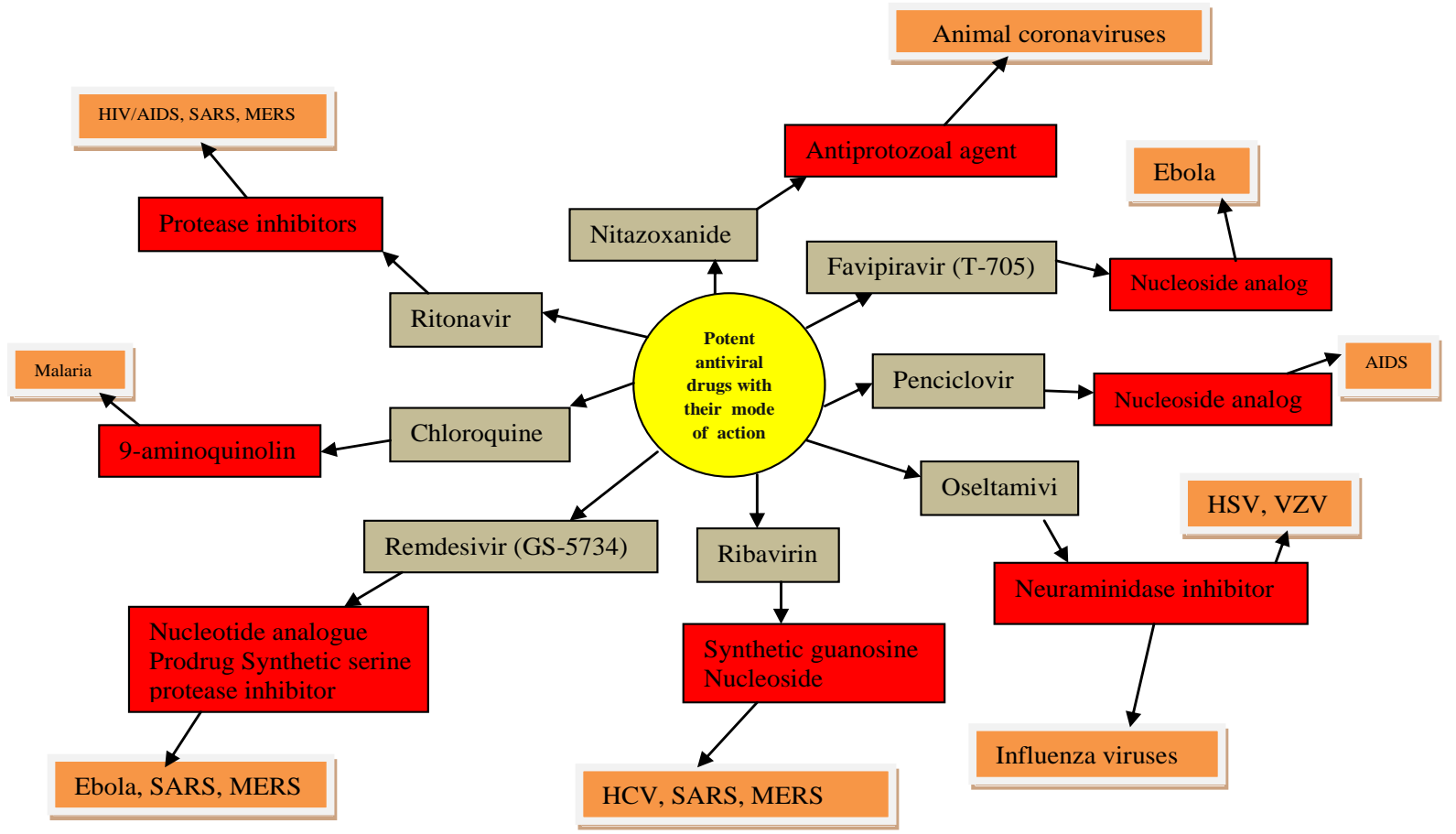

Figure 7 Showing common and potent antiviral drugs with their mode of action (Reproduced from Razonable, 2011 under Creative Commons Attribution (CC BY) licence, permission granted by "Elsevier")

Journal of Experimental Biology and Agricultural Sciences

http://www.jebas.org 
$\left(\mathrm{NO}_{2}\right)$, a toxic factor, may also favor COVID-19 (Ogen, 2020; Bilal et al., 2020c; Ihsanullah et al., 2020). $\mathrm{NO}_{2}$ reaches the environment through anthropogenic behaviour and natural mechanisms (lighting and land systems) (mostly the burning of fossil fuel from cars and power plants). Large sensitivity with $\mathrm{NO}_{2}$ is associated with hypertension (Shin et al., 2020), cardiovascular disorders (Gan et al., 2012; Mann Jennifer et al., 2002), improved inpatient treatment (Mann Jennifer et al., 2002), chronic obstructive pulmonary disorder (COPD), weak lung development deficits in infants, or impaired lung function in adults, (Rubenfeld et al., 2005; Bowatte et al., 2017) or diabetes (Saeha et al., 2020); and weak lungs capacity (James Gauderman et al., 2000; Avol et al., 2001). The assessment of NO2 concentration as the contribution of factors for hypertension, diabetes, heart and cardiovascular disease which promoted the infection of SARS$\mathrm{CoV}-2$, and the higher exposure further induced the mortality of patients (Ogen, 2020). This analysis has been assessed in different regions in Italy, Spain, France, and Germany, which showed 78\% death, due to high exposure of $\mathrm{NO}_{2}$. Other studies have focused on responding to $\mathrm{NO}_{2}$ exposure for the adverse effect on the immune system (Blomberg et al., 1999) and found that $\mathrm{NO}_{2}$ exposure induces inflammatory responses in the respiratory systems and increased synthesis of pro-inflammatory cytokines in the human cells. Exposure to road traffic noise has been correlated with the incidence of hypertension and diabetes in Toronto, Canada (Shin et al., 2020). In addition, the presence of $\mathrm{NO}_{2}$ may contribute to epithelial cells becoming special in the lung (Persinger et al., 2002). Ice mortality (Chen et al. 2007; Beelen et al., 2008; Hoek, et al., 2013) is strongly correlated with elevated $\mathrm{NO}_{2}$ rates and is also responsible for certain dangerous secondary contaminants, such as ozone $\left(\mathrm{O}_{3}\right)$ and nitric acid $\left(\mathrm{HNO}_{3}\right)$ (Khoder, 2002). The WHO has also confirmed that the existence of $\mathrm{NO}_{2}$ or its secondary products may theoretically trigger health hazards (WHO, 2003).

\section{Preventive measures for safeguarding against COVID-19}

1. Put face mask whenever going out to prevent SARS$\mathrm{CoV}-2$ infection. Wearing the face shield is also recommended

2. Follow appropriate hygiene, clean yourself, and wear washed and clean clothes.

3. Regular washing of hands with medicated soap and clean water.

4. Take simple and easily digestive, balanced food to maintain energy and boost immunity

5. Maintain regular walking and other physical exercises for body fitness
6. Hold the social distance from each other of at least 1 meter ( 3 feet) or more

7. Keep positive thoughts to maintain immunity and avoid excess stress conditions

8. Ensure the proper respiratory health suits you as well as the surrounding people of yourself, while sneezing and coughing follow appropriate measures of covering mouth and nose with some clothes or napkins, and disinfect or dispose of these properly

9. Stay at home and relieve yourself, if any infection is there and don't walk out before you heal, particularly when there are slight signs of cough, headache, and moderate fever, and consult a medical doctor

10. If you have fatigue, cough, and respiratory issues, take adequate professional advice and treatment, and inform local health authorities and follow their guidelines

11. Be informed with regards to the latest information, updates, and guidelines as prescribed by WHO or the local and national health agencies, on reliable websites

12. Keep hand sanitizers focused on alcohol out of the reach of infants. Know how to use the sanitizers and disinfection procedures.

\section{Conclusion and future prospects}

The knowledge gained and some newer insights on SARS-CoV-2 genomic organization, molecular biology, Pathobiology, and progress in developing effective drugs and therapies for treating COVID-19 patients have been presented in this review article. The sequence data analysis of SARS-CoV-2 revealed its origin from the bats sold in the seafood market of Wuhan city of china and pangolins. Further, the virus got adopted to humans and gained rapid replication for transmission from human-to-human. Crossspecies jumping and spillover of the SARS-CoV have been reported. Besides, the virus has been obtained from other animals like dogs, cats, lion, and mink as a host. But the investigation of SARS-CoV-2 revealed that obtained pathogen was quite different from the previously reported virus as a MERS-CoV during 2002 and 2012 as a serious disease. Moreover, this novel emerging virus has higher transmission rates, though it has a lower mortality rate. Typically, SARS-CoV-2 has shown multiple routes of transmission along with multiple clinical manifestations, which need to be evaluated further. The severity of COVID-19 increases in the infected patient with the new virus due to pre-existing other diseases such as diabetes, heart diseases, hypertension and other associated risk factors including old age. Due to a lack of vaccines and drugs, timely diagnosis along with appropriate prevention and 
control strategies could help to control the infection and spread of the virus. Moreover, the good food habit with balance nutrient and other herbal medicines along with physical exercises and Yoga has been reported to enhance immunity for the prevention with this virus infection. The detailed understanding regarding the SARSCoV-2 genetic material, molecular biology, pathology, pathobiology, immunity, immunobiology, evolutionary and transmission events, intermediate hosts, zoonotic concerns would assist to understand better this pandemic virus, the disease it causes, and to find out effective vaccine candidates, anti-viral medicines and therapeutic treatments.

\section{Acknowledgments}

All the authors acknowledge their respective University and Institute. This article as a part of progress under a project funded from the Department of Biotechnology (DBT), Govt. of India as Grant-in-Aid Project (Letter No. BT/ PR13922/ BCE/ 8/1129/ 2015) to Prof. Ram Chandra.

\section{Conflicts of Interest}

The authors declare that the review was conducted in the absence of any commercial or financial relationships that could be construed as a potential conflict of interest

\section{Authors' Contribution}

All the listed author(s) have made a substantial, direct, and intellectual contribution to the work, and approved it for publication

\section{Funding}

None

\section{Ethics Statement}

This article does not contain any studies with human participants or animals performed by any of the authors

\section{Availability of Data}

Not applicable.

\section{References}

Abbott TR, Dhamdhere G, Liu Y, Lin X, Goudy, Zeng L, Pande T (2020) Development of CRISPR as an antiviral strategy to combat SARS-CoV-2 and influenza. Cell 181(4):865-876.e12. doi: 10.1016/j.cell.2020.04.020.

Adamo M, Lombardi CM, Metra M (2020) at a glance: focus on COVID-19, quality of life, and comorbidities. European Journal of Heart Failure 22(6):917-918. doi: 10.1002/ejhf.1515.
Agostini A, Floridi C, Borgheresi A, Badaloni M, Pirani PE, Terilli F, Giovagnoni A (2020) Proposal of a low-dose, long-pitch, dualsource chest CT protocol on third-generation dual-source CT using a tin filter for spectral shaping at $100 \mathrm{kVp}$ for CoronaVirus Disease 2019 (COVID-19) patients: a feasibility study. La Radiology Medica 125 (4): 365-373. doi: https://doi.org/10.1007/s11547-02001179-x

Ahmad T, Haroon, Baig M, Hui J (2020a) Coronavirus Disease 2019 (COVID-19) Pandemic and Economic Impact. Pakistan Journal of Medicinal Science 36(COVID19-S4): S73-S78.

Ahmad T, Haroon, Dhama K, Sharun K, Khan FM, Ahmed I, Tiwari R, Musa TH, Khan M, Bonilla-Aldana DK, J RodriguezMorales A, Hui J (2020b) Biosafety and biosecurity approaches to restrain/contain and counter SARS-CoV-2/COVID-19 pandemic: a rapid-review. Turkish Journal of Biology 44(3): 132-145.

Ahuja AS, Reddy VP, Marques O (2020) Artificial intelligence and COVID-19: A multidisciplinary approach. Integrated Medicinal Research 9(3):100434. doi:10.1016/j.imr.2020.100434

Altay O, Mohammadi E, Lam S, Turkey H, Boren J, Nielsen J, Uhlen M, Mardinoglu A (2020) Current Status of COVID-19 Therapies and Drug Repositioning Applications. Iscience 23(7):101303. doi: 10.1016/j.isci.2020.101303.

Anderson DE, Cui J, Ye Q, Huang B, Zu W, Gong J, Liu W, Kim SY, Yan BG, Sigmundsson K, Lim XF, Ye F, Niu P, Zhou X, Tan W, Wang L, Tan X (2020) Orthogonal genome-wide screenings in bat cells identify MTHFD1 as a target of broad antiviral therapy. bioRxiv; 2020. DOI: 10.1101/2020.03.29.014209.

Apicella M, Campopiano MC, Mantuano M, Mazoni L, Coppelli A, Del Prato S (2020) COVID-19 in people with diabetes: understanding the reasons for worse outcomes. Lancet Diabetes and Endocrinology S2213-8587(20)30238-2. doi:10.1016/S22138587(20)30238-2.

Araki K, Gangappa S, Dillehay DL, Rouse BT, Larsen CP, Ahmed R (2010) Pathogenic virus-specific T cells cause disease during treatment with the calcineurin inhibitor FK506: implications for transplantation. Journal of Experimental Medicine 207(11): 23552367.

Arndt AL, Blake J. Larson BJ, Hogue BG (2011) A conserved domain in the coronavirus membrane protein tail is important for virus assembly. Journal of Virology 84(21): 11418-11428. doi:10.1128/JVI.01131-10.

Arts RJW, Moorlag SJCFM, Novakovic B, Li Y, Wang SY, Oosting M, Kumar V, Xavier RJ, Wijmenga C, Joosten LAB, Reusken CBEM, Benn CS, Aaby P, Koopmans MP, Stunnenberg 
HG, van Crevel R, Netea MG (2018). BCG Vaccination Protects against Experimental Viral Infection in Humans through the Induction of Cytokines Associated with Trained Immunity. Cell Host Microbe 23(1):89-100.e5. doi: 10.1016/j.chom.2017.12.010.

Arumugam VA, Thangavelu S, Fathah Z, et al. (2020) COVID-19 and the World with Co-Morbidities of Heart Disease, Hypertension and Diabetes. Journal of Pure and Applied Microbiology 14(3):1623-1638. doi: 10.22207/JPAM.14.3.01.

Assiri A, McGeer A, Perl TM, Price CS, Al Rabeeah AA, Cummings DA, Madani H (2013). Hospital outbreak of Middle East respiratory syndrome coronavirus. New England Journal of Medicine 369(5): 407-416. DOI: 10.1056/NEJMoa1306742.

Avol EL, Gauderman WJ, Tan SM, London SJ, Peters JM (2001) Respiratory effects of relocating to areas of differing air pollution levels. American Journal of Respiratory and Critical Care Medicine 164(11): 2067-2072. DOI: 10.1164/rccm2102005.

Ayittey FK, Ayittey MK, Chiwero NB, Kamasah JS, Dzuvor C (2020) Economic Impacts of Wuhan 2019-nCoV on China and the World. Journal of Medical Virology 92(5): 473-475. doi: 10.1002/jmv.25706.

Bachanova V, Bishop MR, Dahi P, Dholaria B, Grupp SA, HayesLattin B, Janakiram M, Maziarz RT, McGuirk JP, Nastoupil LJ, Oluwole OO, Perales MA, Porter DL, Riedell PA (2020) CAR Tcell Consortium. Chimeric Antigen Receptor T Cell Therapy During the COVID-19 Pandemic. Biology of Blood and Marrow Transplantation 26(7):1239-1246. 10.1016/j.bbmt.2020.04.008.

Baradaran A, Ebrahimzadeh MH, Baradaran A, Kachooei AR (2020) Prevalence of Comorbidities in COVID-19 Patients: A Systematic Review and Meta-Analysis. The Archives of Bone and joint surgery 8(Suppl 1):247-255. doi:10.22038/abjs.2020.47754.2346

Baranov PV, Henderson CM, Anderson CB, Gesteland RF, Atkins JF, Howard, MT (2005) Programmed ribosomal frame shifting in decoding the SARS-CoV genome. Virology 332(2), 498-510.

Barbuddhe SB, Rawool DB, Gaonkar PP, Vergis J, Dhama K, Malik SS (2020) Global scenario, public health concerns and mitigation strategies to counter current ongoing SARS-CoV-2 / COVID-19 pandemic. Human Vaccines and Immunotherapeutics 16(12): doi: 10.1080/21645515.2020.1810496.

Bárcena M, Oostergetel GT, Bartelink W, Faas FG, Verkleij A, Rottier PJ Bosch BJ (2009) Cryo-electron tomography of mouse hepatitis virus: insights into the structure of the corona vision. Proceedings of the National Academy of Sciences 106(2): 582-587.
Beelen R, Hoek G, van Den Brandt PA, Goldbohm RA, Fischer P, Schouten LJ, Brunekreef B (2008) Long-term effects of trafficrelated air pollution on mortality in a Dutch cohort (NLCS-AIR study). Environmental Health Perspectives 116(2): 196-202.

Belouzard S, Chu VC, Whittaker GR (2009) Activation of the SARS coronavirus spike protein via sequential proteolytic cleavage at two distinct sites. Proceedings of the National Academy of Sciences 106(14): 5871-5876.

Beniac DR, Andonov A, Grudeski E, Booth TF (2006). The architecture of the SARS coronavirus prefusion spike. Nature Structural \& Molecular Biology 13(8): 751-752.

Bilal M, Iqbal HM (2020) Recent advances in therapeutic modalities and vaccines to counter COVID-19/SARS-CoV2. Human Vaccines \& Immunotherapeutics, 1-9. DOI: https://doi.org/10.1080/21645515.2020.1794685.

Bilal M, Nazir MS, Ahmed I, Iqbal H (2020b) Coronaviruses and COVID-19-Complications and Lessons Learned for the Future. Journal of Pure and Applied Microbiology 1(14): 725-731, 20200416.

Bilal M, Nazir MS, Parra-Saldivar R, Iqbal HM (2020a) ncov/covid19-approaches to viral vaccine development and preventive measures. Journal of Pure and Applied Microbiology 14(1): 25-29.

Bilal M, Nazir MS, Rasheed T, Parra-Saldivar R, Iqbal HM (2020c) Water matrices as potential source of SARS-CoV-2 transmission-An overview from environmental perspective. Case Studies in Chemical and Environmental Engineering, 100023.DOI: https://doi.org/10.1016/j.cscee.2020.100023.

Blomberg A, Krishna, MT, Helleday R, Soderberg M, Ledin MC, Kelly FJ, Sandstrom T (1999). Persistent airway inflammation but accommodated antioxidant and lung function responses after repeated daily exposure to nitrogen dioxide. American Journal of Respiratory and Critical Care Medicine 159(2): 536-543.

Bonilla-Aldana DK, Dhama K, Rodriguez-Morales AJ (2020) Revisiting the One Health Approach in the Context of COVID-19: A look into the Ecology of this Emerging Disease. Advances in Animal and Veterinary Sciences 8(3):234-237.

Boscarino JA, Logan HL, Lacny JJ, Gallagher TM (2008) Envelope protein palmitoylations are crucial for murine coronavirus assembly. Journal of Virology 82: 2989-2999.

Bosch BJ, van der Zee R, de Haan CA, Rottier PJ (2003) The coronavirus spike protein is a class I virus fusion protein: structural and functional characterization of the fusion core complex. Journal of Virology 77(16):8801-8811. 
Bowatte G, Erbas B, Lodge CJ, Knibbs LD, Gurrin LC, Marks GB, Dennekamp M (2017) Traffic-related air pollution exposure over a 5 -year period is associated with an increased risk of asthma and poor lung function in middle age. European Respiratory Journal 50(4): 1602357.

Braun J, Loyal L, Frentsch M, Wendisch D, Georg P, Kurth F, Hippenstiel S, Dingeldey M, Kruse B, Fauchere F, Baysal E, Mangold M, Henze L, Lauster R, Mall MA, Beyer K, Röhmel J, Voigt S, Schmitz J, Miltenyi S, Demuth I, Müller MA, Hocke A, Witzenrath M, Suttorp N, Kern F, Reimer U, Wenschuh H, Drosten C, Corman VM, Giesecke-Thiel C, Sander LE, Thiel A (2020) SARS-CoV-2-reactive $\mathrm{T}$ cells in healthy donors and patients with COVID-19. Nature. doi: 10.1038/s41586-020-2598-9.

Brierley I, Digard P, Inglis, SC (1989) Characterization of an efficient coronavirus ribosomal frameshifting signal: requirement for an RNA pseudoknot. Cell 57(4): 537-547. https://doi.org/10.1016/0092-8674(89)90124-4.

Brown CG, Nixon KS, Senanayake SD, Brian DA (2007) An RNA stem-loop within the bovine coronavirus nsp1 coding region is a cis-acting element in defective interfering RNA replication. Journal of Virology 81(14): 7716-7724.

Caccamo N, Sullivan LC, Brooks AG, Dieli F (2020) Harnessing HLA-E-restricted CD8 T lymphocytes for adoptive cell therapy of patients with severe COVID-19. British Journal of Haematology DOI: 1:10.1111/bjh.16895. doi: 10.1111/bjh.16895.

Caly L, Druce JD, Catton MG, Jans DA, Wagstaff KM (2020) The FDA-approved drug ivermectin inhibits the replication of SARSCoV-2 in vitro. Antiviral Research 178:104787. doi: 10.1016/Journal of Antiviral Research 2020.104787.

Casadevall A, Pirofski LA (2020) The convalescent sera option for containing COVID-19. Journal of Clinical Investigation 4: 15451548. https://doi.org/10.1172/JCI138003.

Chen L, Hu C, Hood M, Zhang X, Zhang L, Kan J, Du J (2020c) A Novel Combination of Vitamin C, Curcumin and Glycyrrhizic Acid Potentially Regulates Immune and Inflammatory Response Associated with Coronavirus Infections: A Perspective from System Biology Analysis. Nutrients 12(4):1193. doi: 10.3390/nu12041

Chen L, Xiong J, Bao L, Shi Y (2020b) Convalescent plasma as a potential therapy for COVID-19. The Lancet Infectious Diseases 20(4):398-400. doi:10.1016/S1473-3099(20)30141-9

Chen N, Zhou M, Dong X, Qu J, Gong F, Han Y, Yu T (2020a) Epidemiological and clinical characteristics of 99 cases of 2019 novel coronavirus pneumonia in Wuhan, China: a descriptive study. The Lancet 395(10223): 507-513.
Chen TM, Kuschner WG, Gokhale J, Shofer S (2007) Outdoor air pollution: nitrogen dioxide, sulfur dioxide, and carbon monoxide health effects. The American Journal of the Medical Sciences 333(4): 249-256.

Chen X, Hu W, Ling J, Mo P, Zhang Y, Jiang Q, Ma Z, Cao Q, Deng L, Song S, et al: (2020d) Hypertension and Diabetes Delay the Viral Clearance in COVID-19 Patients. medRxiv. 2020.2003.2022.20040774.

Chen Y, Liu Q, Guo D (2020e) Emerging coronaviruses: genome structure, replication, and pathogenesis. Journal of Medical Virology 92(4): 418-423. Doi: 10.1002/jmv.25681

Cheng PK, Wong DA, Tong LK, Ip SM, Lo AC, Lau CS, Lim WW (2004) Viral shedding patterns of coronavirus in patients with probable severe acute respiratory syndrome. The Lancet 363(9422): 1699-1700.

Choy KT, Wong AY, Kaewpreedee P, Sia SF, Chen D, Hui KPY, Chu DKW, Chan MCW, Cheung PP, Huang X, Peiris M, Yen HL (2020) Remdesivir, lopinavir, emetine, and homoharringtonine inhibit SARS-CoV-2 replication in vitro. Antiviral Research 178:104786. doi: 10.1016/j.antiviral.2020.104786.

Chu DK, Akl EA, Duda S, Solo K, Yaacoub S, Schünemann HJ, El-harakeh A, Bognanni A, Lotfi T, Loeb M, Hajizadeh A (2020) Physical distancing, face masks, and eye protection to prevent person-to-person transmission of SARS-CoV-2 and COVID-19: a systematic review and meta-analysis. The Lancet 395: ISSUE 10242, P1973-1987, doi.org/10.1016/S0140-6736(20)31142-9

Chu DK, Poon LL, Gomaa MM, Shehata MM, Perera RA, Zeid DA, El Rifay AS, Siu LY, Guan Y, Webby RJ, Ali MA (2014) MERS coronaviruses in dromedary camels, Egypt. Emerging Infectious Diseases 20(6):1049.

Ciotti M, Ciccozzi M, Terrinoni A, Jiang WC, Wang CB, Bernardini S (2020) The COVID-19 pandemic. Critical Reviews in Clinical Laboratory Sciences 57(6):365-388.

Cornelissen LA, Wierda CM, Van Der Meer FJ, Herrewegh AA, Horzinek, MC, Egberink HF, De Groot, RJ (1997) Hemagglutininesterase, a novel structural protein of torovirus. Journal of Virology 71(7): 5277-5286.

Cui J, Li F, Shi ZL (2019) Origin and evolution of pathogenic coronaviruses. Nature Reviews Microbiology 17(3): 181-192.

de Groot RJ, Baker SC, Ralph RS, Brown CS, Drosten C, Enjuanes L, et al. (2013) Middle East Respiratory Syndrome Coronavirus (MERS-CoV): Announcement of the Coronavirus Study Group Journal of Virology 87(14): 7790-7792. 
De Hanan CA, Kuo L. Master PS, Vennema H, Rottier PJ (1998) Coronavirus particle assembly: primary structure requirement of the membrane protein. Journal of Virology 72:6838-6850.

Delmas BERNARD, Laude H U B E R T (1990) Assembly of coronavirus spike protein into trimers and its role in epitope expression. Journal of Virology 64(11): 5367-5375.

Devaux CA, Rolain JM, Colson P, Raoult D (2020) New insights on the antiviral effects of chloroquine against coronavirus: what to expect for COVID-19? International Journal of Antimicrobial Agents 55(5):105938. doi: 10.1016/j.ijantimicag.2020.105938.

Dhama K, Karthik K, Khandia R, Munjal A, Tiwari R, Rana R, Khurana SK, Sana Ullah, Khan RU, Alagawany M, Farag MR, Dadar M, Joshi SK (2018) Medicinal and therapeutic potential of herbs and plant metabolites/extracts countering viral pathogens Current knowledge and future prospects. Current Drug Metabolism 19(3):236-263. doi: 10.2174/1389200219666180129145252.

Dhama K, Khan S, Tiwari R, Sircar S, Bhat S, Malik YS, Singh KP, Chaicumpa W, Bonilla-Aldana DK, Rodriguez-Morales AJ (2020a) Coronavirus Disease 2019-COVID-19. Clinical Microbiology Reviews 33(4):e00028-20.

Dhama K, Patel SK, Pathak M, Yatoo MI, Tiwari R, Malik YS, Singh R, Sah R, Rabaan AA, Bonilla-Aldana DK, RodriguezMorales AJ (2020b) An update on SARS-CoV-2/COVID-19 with particular reference to its clinical pathology, pathogenesis, immunopathology and mitigation strategies. Travel Medicine and Infectious Disease 101755.

Dhama K, Saminathan M, Jacob SS, Singh M, Karthik K, Amarpal, Tiwari R, Sunkara LT, Malik YS, Singh RK (2015) Effect of immunomodulation and immunomodulatory agents on health with some bioactive principles, modes of action, and potent biomedical applications. International Journal of Pharmacolology 11(4): 253-290.

Dhama K, Sharun K, Tiwari R, Dadar M, Malik YS, Singh KP, Chaicumpa W (2020c) COVID-19, an emerging coronavirus infection: advances and prospects in designing and developing vaccines, immunotherapeutics, and therapeutics. Human Vaccines and Immuno therapeutics 16(6):1232-1238.

Duan K, Liu B, Li C, Zhang H, Yu T, Qu J, Zhou M, Chen L, Meng $S$, et al. (2020) Effectiveness of convalescent plasma therapy in severe COVID-19 patients. Proceedings of National Academy of Sciences USA 117(17): 9490-9496. doi: 10.1073/pnas.2004168117.

Fehr AR, Perlman S (2015) Coronaviruses: an overview of their replication and pathogenesis. In Coronaviruses (pp. 1-23). Humana Press, New York, NY.
Felsenstein S, Herbert JA, McNamara PS, Hedrich CM (2020) COVID-19: Immunology and treatment options. Clinical Immunology 2020;215:108448. doi:10.1016/j.clim.2020.108448.

Fu B, Xu X, Wei H (2020) Why tocilizumab could be an effective treatment for severe COVID-19? Journal of Translational Medicine 18(1):164. doi: 10.1186/s12967-020-02339-3.

Gabarre P, Dumas G, Dupont T, Darmon M, Azoulay E, Zafrani L (2020) Acute kidney injury in critically ill patients with COVID19. Intensive Care Medicine. doi: 10.1007/s00134-020-06153-9.

Galanakis CM (2020) The Food Systems in the Era of the Coronavirus (COVID-19) Pandemic Crisis. Foods 4: 523. https://doi.org/10.3390/foods9040523.

Gan WQ, Davies HW, Koehoorn M, Brauer M (2012) Association of long-term exposure to community noise and traffic-related air pollution with coronary heart disease mortality. American Journal of Epidemiology 175(9): 898-906.

Gangal N, Nagle V, Pawar Y, Dasgupta S (2020) Reconsidering Traditional Medicinal Plants to Combat COVID-19. AIJR Preprints 2020; https://preprints.aijr.org/index.php/ap/preprint/view/34.

Gao J, Tian Z, Yang X (2020) Breakthrough: Chloroquine phosphate has shown apparent efficacy in the treatment of COVID-19 associated pneumonia in clinical studies. Bio Science Trends 14(1):72-73. doi: 10.5582/bst.2020.01047.

Gassen NC, Niemeyer D, Muth D, Corman VM, Martinelli S, Gassen A, Hafner K, Papies J, Mösbauer K, Zellner A, Zannas AS, Herrmann A, Holsboer F, Brack-Werner R, Boshart M, MüllerMyhsok B, Drosten C, Müller MA, Rein T (2019) SKP2 attenuates autophagy through Beclin1-ubiquitination and its inhibition reduces MERS-Coronavirus infection. Nature Communications 10(1):5770. doi: 10.1038/s41467-019-13659-4.

Ge XY, Li JL, Yang XL, Chmura AA, Zhu G, Epstein JH, Zhang YJ (2013) Isolation and characterization of a bat SARS-like coronavirus that uses the ACE-2 receptor. Nature 503(7477): 535-538.

Giacca M, Bussani R, Schneider E, Zentilin L, Collesi C, Ali H, Braga L, Secco I, Volpe MC, Colliva A, Zanconati F (2020) Persistence of viral RNA, widespread thrombosis and abnormal cellular syncytia are hallmarks of COVID-19 lung pathology. medRxiv. 2020 Jan 1.

Golonka RM, Saha P, Yeoh BS, Chattopadhyay S, Gewirtz AT, Joe B, Vijay-Kumar M (2020) Harnessing innate immunity to eliminate SARS-CoV-2 and ameliorate COVID-19 disease. Physiological Genomics 52(5):217-221. doi: 10.1152/physiolgenomics.00033.2020. 
Guan BJ, Wu HY, Brian DA (2011) An optimal cis-replication stem-loop IV in the $5^{\prime}$ untranslated region of the mouse coronavirus genome extends 16 nucleotides into open reading frame 1. Journal of Virology 85(11): 5593-5605.

Guan WJ, Chen RC, Zhong NS (2020b) Strategies for the prevention and management of coronavirus disease in 2019. European Respiratory Journal 55(4):2000597. doi:10.1183/13993003.00597-2020

Guan WJ, Ni ZY, Hu Y, Liang WH, Ou CQ, He JX, Du B (2020a) Clinical characteristics of coronavirus disease in 2019 in China. New England Journal of Medicine 382(18):1708-1720.

Guan Y, Zheng BJ, He YQ, Liu XL, Zhuang ZX, Cheung CL, Luo SW, Li PH, Zhang LJ, Guan YJ, Butt KM (2003) Isolation and characterization of viruses related to the SARS coronavirus from animals in southern China. Science 302(5643):276-8.

Guo YR, Cao QD, Hong ZS, Tan YY, Chen SD, Jin HJ, Yan Y (2020) The origin, transmission, and clinical therapies on coronavirus disease 2019 (COVID-19) outbreak-an update on the status. Military Medical Research 7(1): 1-10.

Gupta A (2020) Is Immuno-modulation the Key to COVID-19 Pandemic? Indian Journal of Orthopaedics, 27: 1-4.

Guy RK, Di Paola RS, Romanelli F, Dutch RE (2020) Rapid repurposing of drugs for COVID-19. Science 368(6493):829-830. doi: $10.1126 /$ science.abb9332.

Halpin DMG, Singh D, Hadfield RM (2020) Inhaled corticosteroids and COVID-19: a systematic review and clinical perspective. European Respiratory Journal 55(5):2001009. doi: 10.1183/13993003.01009-2020.

Henry BM, Lippi G (2020) chronic kidney disease is associated with severe coronavirus disease 2019 (COVID-19) infection. International Urology and Nephrology 52(6):1193-1194. Doi: 10.1007/s11255-020-02451-9.

Hoek G, Krishnan RM, Beelen R, Peters A, Ostro B, Brunekreef B, Kaufman JD (2013) Long-term air pollution exposure and cardiorespiratory mortality: a review. Environmental Health 12(1): 43.

Holshue ML, DeBolt C, Lindquist S, Lofy KH, Wiesman J, Bruce H, Spitters C, Ericson K, Wilkerson S, Tural A, Diaz G, Cohn A, Fox L, Patel A, Gerber SI, Kim L, Tong S, Lu X, Lindstrom S, Pallansch MA, Weldon WC, Biggs HM, Uyeki TM, Pillai SK (2020) Washington State 2019-nCoV Case Investigation Team. First Case of 2019 Novel Coronavirus in the United States. New England Journal of Medicine 382(10):929-936. doi: 10.1056/NEJMoa2001191. https://www.worldometers.info/coronavirus/. Accessed on $13^{\text {th }}$ November, 2020.

Huang C, Wang Y, Li X, Ren L, Zhao J, Hu Y, Cheng Z (2020b) Clinical features of patients infected with 2019 novel coronavirus in Wuhan, China. The Lancet 395(10223): 497-506.

Huang Y, Tu M, Wang S, Chen S, Zhou W, Chen D, Zhou L, Wang M, Zhao Y, Zeng W, Huang Q (2020a) Clinical characteristics of laboratory confirmed positive cases of SARSCoV-2 infection in Wuhan, China: A retrospective single center analysis. Travel Medicine and Infectious Disease 36:101606. doi: 10.1016/j.tmaid.2020.101606.

Huang Y, Yang C, Xu XF, Xu W, Liu SW (2020c) Structural and functional properties of SARS-CoV-2 spike protein: potential antivirus drug development for COVID-19. Acta Pharmacologica Sinica 41(9):1141-1149. doi: 10.1038/s41401-020-0485-4.

Hurst KR, Koetzner CA, Masters PS (2009) Identification of in vivo-interacting domains of the murine coronavirus nucleocapsid protein. Journal of Virology 83(14): 7221-7234.

Hurst KR, Koetzner CA, Masters PS (2013) Characterization of a critical interaction between the coronavirus nucleocapsid protein and non structural protein 3 of the viral replicase-transcriptase complex. Journal of Virology 87(16): 9159-9172.

Ianevski A, Yao R, Fenstad MH, Biza S, Zusinaite E, Reisberg T, Lysvand H, Løseth K, Landsem VM, Malmring JF, Oksenych V, Erlandsen SE, Aas PA, Hagen L, Pettersen CH, Tenson T, Afset JE, Nordbø SA, Bjørås M, Kainov DE (2020) Potential Antiviral Options against SARS-CoV-2 Infection. Viruses 12(6):642. doi: 10.3390/v12060642.

Ihsanullah I, Bilal M, Naushad M (2020) Coronavirus 2 (SARS$\mathrm{CoV}-2)$ in water environments: Current status, challenges and research opportunities. Journal of Water Process Engineering 101735.

Infusino F, Marazzato M, Mancone M, Fedele F, Mastroianni CM, Severino P, Ceccarelli G, Santinelli L, Cavarretta E, Marullo AGM, Miraldi F, Carnevale R, Nocella C, Biondi-Zoccai G, Pagnini C, Schiavon S, Pugliese F, Frati G, d'Ettorre G (2020) Diet Supplementation, Probiotics, and Nutraceuticals in SARS-CoV-2 Infection: A Scoping Review. Nutrients 12(6):E1718. doi: 10.3390/nu12061718.

Iwabuchi K, Yoshie K, Kurakami Y, Takahashi K, Kato Y, Morishima T (2020) Therapeutic potential of ciclesonide inahalation for COVID-19 pneumonia: Report of three cases. Journal of infection and chemotherapy 26(6):625-632. doi: 10.1016/j.jiac.2020.04.007. 
Jaggers GK, Watkins BA, Rodriguez RL (2020) COVID-19: Repositioning nutrition research for the next pandemic. Nutrition Research doi: 10.1016/j.nutres.2020.07.005.

Jahan I, Onay A (2020) Potentials of plant-based substance to inhabit and probable cure for the COVID-19. Turkish Journal of Biology 44(3):228-241. doi: 10.3906/biy-2005-114.

Jahanshahlu L, Rezaei N (2020) Monoclonal antibody as a potential anti-COVID-19. Biomedicne and Pharmacotherapy 129:110337. doi: 10.1016/j.biopha.2020.110337.

James-Gauderman, W, McConnell ROB, Gilliland F, London S, Thomas D, Avol E, Margolis HG (2000) Association between air pollution and lung function growth in southern California children. American Journal of Respiratory and Critical Care Medicine 162(4): 1383-1390.

Jang CH, Choi JH, Byun MS, Jue DM (2006) Chloroquine inhibits the production of TNF-alpha, IL-1beta, and IL-6 from lipopolysaccharide-stimulated human monocytes/macrophages by different modes. Rheumatology (Oxford) 45(6):703-10. doi: 10.1093/rheumatology/kei282.

Jayawardena R, Sooriyaarachchi P, Chourdakis M, Jeewandara C, Ranasinghe P (2020) Enhancing immunity in viral infections, with special emphasis on COVID-19: A review. Diabetes, Metabolic Syndrome and Obesity: Targets and Therapy 14(4):367-382. doi: 10.1016/j.dsx.2020.04.015.

Jeon S, Ko M, Lee J, Choi I, Byun SY, Park S, Shum D, Kim S (2020) Identification of Antiviral Drug Candidates against SARSCoV-2 from FDA-Approved Drugs. Antimicrobial Agents and Chemotherapy 64(7):e00819-20. doi: 10.1128/AAC.00819-20.

Kazi L, Lissenberg A, Watson R, de Groot RJ, Weiss SR (2005) Expression of hemagglutinin esterase protein from the recombinant mouse hepatitis virus enhances Neuro virulence. Journal of Virology 79(24): 15064-15073.

Keam S, Megawati D, Patel SK, Tiwari R, Dhama K, Harapan H (2020) Immunopathology, and immunotherapeutic strategies in severe acute respiratory syndrome coronavirus 2 infections. Reviews in Medical Virology 10.1002/rmv.2123. doi:10.1002/rmv.2123.

Keni R, Alexander A, Nayak PG, Mudgal J, Nandakumar K (2020) COVID-19: Emergence, Spread, Possible Treatments, and Global Burden. Frontiers in Public Health 8: 216.

Khoder MI (2002) Atmospheric conversion of sulfur dioxide to particulate sulfate and nitrogen dioxide to particulate nitrate and gaseous nitric acid in an urban area. Chemosphere 49(6): 675-684.
Kubo H, Yamada YK, Taguchi F (1994) Localization of neutralizing epitopes and the receptor-binding site within the amino-terminal 330 amino acids of the murine coronavirus spike protein. Journal of Virology 68(9): 5403-5410.

Kumar GV, Jeyanthi V, Ramakrishnan S (2020) A short review on antibody therapy for COVID-19. New Microbes and New Infections 35: 100682. https://doi.org/10.1016/j.nmni.2020.100682.

Kuo L, Masters PS (2013) Functional analysis of the murine coronavirus genomic RNA packaging signal. Journal of Virology 87(9): 5182-5192.

Lau SK, Woo PC, Li KS, Huang Y, Tsoi HW, Wong BH, Wong SS, Leung SY, Chan KH, Yuen KY (2005) severe acute respiratory syndrome coronavirus-like virus in Chinese horseshoe bats. Proceedings of the National Academy of Sciences 102(39):14040-5.

Laura Riva, Shuofeng Yuan, Xin Yin, Laura Martin-Sancho, et al. (2020) Discovery of SARS-CoV-2 antiviral drugs through largescale compound repurposing. Nature https://doi.org/10.1038/s41586-020-2577-1

Ledford H (2020) Coronavirus breakthrough: dexamethasone is first drug shown to save lives. Nature 582(7813):469. doi: 10.1038/d41586-020-01824-5.

Lei Zha, Shirong Li, Lingling Pan, Boris Tefsen, Yeshan Li, Neil French, et al., (2020) Corticosteroid treatment of patients with coronavirus disease 2019 (COVID-19). The Medicinal Journal of Australia 212 (9): 416-420.

Lenzen M, Li M, Malik A, Pomponi F, Sun YY, Wiedmann T, Faturay F, Fry J, Gallego B, Geschke A, Gómez-Paredes J, Kanemoto K, Kenway S, Nansai K, Prokopenko M, Wakiyama T, Wang Y, Yousefzadeh M (2020) Global socio-economic losses and environmental gains from the Coronavirus pandemic. PLoS One 15(7):e0235654.

Letko M, Marzi A, Munster V (2020) Functional assessment of cell entry and receptor usage for SARS-CoV-2 and other lineage B beta coronaviruses. Nature microbiology 5(4):562-569.

Li C, Wang L, Ren L (2020c) Antiviral mechanisms of candidate chemical medicines and traditional Chinese medicines for SARSCoV-2 infection. Virus Research 286:198073.

Li F (2015) Receptor recognition mechanisms of coronaviruses: A decade of structural studies. Journal of Virology 89(4): 1954-1964.

Li F, Li W, Farzan M, Harrison SC (2005) Structure of SARS coronavirus spike receptor-binding domain complexed with receptor. Science 309: 1864-1868; 
Li L, Gong S, Yan J (2020b) Clinical observation and management of COVID-19 patients. Journal of Emerging Microbes \& Infections 9(1):687-690

Li X, Song Y, Wong G, Cui J (2020a) Bat origin of a new human coronavirus: there and back again. Science China Life Sciences 63(3): 461-462.

Li Y, Liu X, Guo L, Li J, Zhong D, Zhang Y, Clarke M, Jin R (2020d) Traditional Chinese herbal medicine for treating novel coronavirus (COVID-19) pneumonia: protocol for a systematic review and meta-analysis. Systematic Reviews 9(1):75. doi: 10.1186/s13643-020-01343-4.

Liang B, Chen J, Li T, Wu H, Yang W, Li Y (2020) Clinical remission of a critically ill COVID-19 patient treated by human umbilical cord mesenchymal stem cells. Medicine (Baltimore) 99(31):e21429.

Lipworth B, Kuo CR, Lipworth S, Chan R (2020) Inhaled Corticosteroids and COVID-19. American Journal of Respiratory Critical Care Medicine doi: 10.1164/rccm.202005-2000LE.

Lissenberg A, Vrolijk MM, van Vliet AL, Langereis MA, de Groot-Mijnes JD, Rottier PJ, de Groot RJ (2005) Luxury at a cost? Recombinant mouse hepatitis viruses expressing the accessory hemagglutinin esterase protein display reduced fitness in vitro Journal of Virology 79(24):15054-63. doi: 10.1128/JVI.79.24.15054-15063.2005.

Liu J, Cao R, Xu M, Wang X, Zhang H, Hu H, Li Y, Hu Z, Zhong W, Wang M (2020a) Hydroxychloroquine, a less toxic derivative of chloroquine, is effective in inhibiting SARS-CoV-2 infection in vitro. Cell Discovery 6:16. doi: 10.1038/s41421-020-0156-0.

Liu P, Chen W, Chen JP (2019) Viral metagenomics revealed Sendai virus and coronavirus infection of Malayan pangolins (Manis javanica). Viruses 11(11):979.

Liu W, Tao ZW, Wang L, Yuan ML, Liu K, Zhou, L, Ming Y (2020b). Analysis of factors associated with disease outcomes in hospitalized patients with 2019 novel coronavirus disease. Chinese Medical Journal.

Lu G, Hu Y, Wang Q, Qi J, Gao F, Li Y, Zhang Y, Zhang W, Yuan Y, Bao J (2013) Molecular basis of binding between novel human coronavirus MERS-CoV and its receptor CD26. Nature 500: $227-231$.

Lu H (2020) Drug treatment options for the 2019-new coronavirus (2019-nCoV). BioScience Trends 14(1):69-71.

Lu QB, Jiang WL, Zhang X, Li HJ, Zhang XA, Zeng HL, Du J, Yang GL, Zhang LK, Li R, Fang LQ, Li H, Liu W (2020b)
Comorbidities for fatal outcome among the COVID-19 patients: a hospital-based case-control study. Journal of Infection S01634453(20)30507-7. doi: 10.1016/j.jinf.2020.07.026.

Lu R, Zhao X, Li J, Niu P, Yang B, Wu H, Wang W, Song H, Huang B, Zhu N, Bi Y (2020a) Genomic characterisation and epidemiology of 2019 novel coronavirus: implications for virus origins and receptor binding. The Lancet 395(10224):565-74.

Malik YS, Kumar N, Sircar S, Kaushik R, Bhat S, Dhama K, Gupta P, Goyal K, Singh MP, Ghoshal U, El Zowalaty ME, O R V, Yatoo MI, Tiwari R, Pathak M, Patel SK, Sah R, RodriguezMorales AJ, Ganesh B, Kumar P, Singh RK (2020) Coronavirus Disease Pandemic (COVID-19): Challenges and a Global Perspective. Pathogens 9(7): E519.

Mann, JK, Tager IB, Lurmann F, Segal M, Quesenberry Jr, CP, Lugg MM, Van Den Eeden, SK (2002) Air pollution and hospital admissions for ischemic heart disease in persons with congestive heart failure or arrhythmia. Environmental Health Perspectives 110(12): 1247-1252.

Market M, Angka L, Martel AB, Bastin D, Olanubi O, Tennakoon G, Boucher DM, Ng J, Ardolino M, Auer RC (2020) Flattening the COVID-19 Curve With Natural Killer Cell-Based Immunotherapies. Frontiers in Immunology 11:1512. doi: 10.3389/fimmu.2020.01512.

McCarthy MW (2020) Harnessing the potential of CRISPR-based platforms to advance the field of hospital medicine. Expert Review of Anti-infective Therapy 1-7.

Mehta P, McAuley DF, Brown M, Sanchez E, Tattersall RS, Manson JJ, HLH Across Speciality Collaboration (2020) COVID19: consider cytokine storm syndromes and immuno suppression. Lancet 395(10229): 1033.

Melgaço JG, Azamor T, Ano Bom APD (2020) Protective immunity after COVID-19 has been questioned: What can we do without SARS-CoV-2-IgG detection? Cellular Immunology 353:104114. doi: 10.1016/j.cellimm.2020.104114.

Menachery VD, Dinnon KH, Yount BL, McAnarney ET, Gralinski LE, Hale A, Graham RL, Scobey T, Anthony SJ, Wang L, Graham B (2020) Trypsin treatment unlocks barrier for zoonotic bat coronavirus infection. Journal of Virology 94(5):e01774-19. doi: 10.1128/JVI.01774-19

Meo SA, Klonoff DC, Akram J (2020) Efficacy of chloroquine and hydroxychloroquine in the treatment of COVID-19. European Review for Medical and Pharmacological Sciences 24(8):45394547. 
Mielech AM, Chen Y, Mesecar AD, Baker SC (2014) Nidovirus papain-like proteases: multifunctional enzymes with protease, deubiquitinating and deISGylating activities. Virus research 194: 184-190.

Millet JK, Whittaker GR (2015) Host cell proteases: critical determinants of coronavirus tropism and pathogenesis. Virus Research 202: 120-134.

Molenkamp R, Spaan WJ (1997). Identification of a specific interaction between the coronavirus mouse hepatitis virus A59 nucleocapsid protein and packaging signal. Virology 239(1): 7886.

Monchatre-Leroy E, Boué F, Boucher JM, Renault C, Moutou F, Ar Gouilh M, Umhang G (2017) Identification of alpha and beta coronavirus in wildlife species in France: bats, rodents, rabbits, and hedgehogs. Viruses 9(12):364.

Montalvan V, Lee J, Bueso T, De Toledo J, Rivas K (2020) Neurological manifestations of COVID-19 and other coronavirus infections: A systematic review. Clinical Neurology and Neurosurgery 194:105921.

Moorlag SJCFM, Arts RJW, van Crevel R, Netea MG (2019) Non-specific effects of the BCG vaccine on viral infections. Clinical Microbiology and Infection 25(12):1473-1478. doi: 10.1016/j.cmi.2019.04.020.

Morais AHA, Passos TS, Maciel BLL, da Silva-Maia JK (2020) Can Probiotics and Diet Promote Beneficial Immune Modulation and Purine Control in Coronavirus Infection? Nutrients 12(6): E1737. doi: 10.3390/nu12061737.

Müller MA, Corman VM, Jores J, Meyer B, Younan M, Liljander A, Bosch BJ, Lattwein E, Hilali M, Musa BE, Bornstein S (2014) MERS coronavirus neutralizing antibodies in camels, Eastern Africa, 1983-1997. Emerging Infectious Diseases 20(12):2093.

Nal B, Chan C, Kien F, Siu L, Tse J, Chu K, van der Werf S (2005) Differential maturation and subcellular localization of severe acute respiratory syndrome coronavirus surface proteins S, $\mathrm{M}$ and European Journal of General Virology 86(5): 1423-1434.

Netea MG, Domínguez-Andrés J, Barreiro LB, Chavakis T, Divangahi M, Fuchs E, Joosten LAB, van der Meer JWM, Mhlanga MM, Mulder WJM, Riksen NP, Schlitzer A, Schultze JL, Stabell Benn C, Sun JC, Xavier RJ, Latz E (2020) Defining trained immunity and its role in health and disease. Nature Reviews in Immunology 20(6):375-388. doi: 10.1038/s41577-020-0285-6.

Neuman BW, Adair BD, Yoshioka C, Quispe JD, Orca G, Kuhn P, Buchmeier MJ (2006) Supramolecular architecture of severe acute respiratory syndrome coronavirus revealed by electron cryomicroscopy. Journal of Virology 80(16): 7918-7928.

Neuman BW, Kiss G, Kunding AH, Bhella D, Baksh MF, Connelly S, Droese B, Klaus JP, Makino S, Sawicki SG, Siddell SG (2011) Structural analysis of $M$ protein in coronavirus assembly and morphology. Journal of Structural Biology 174(1):11-22.

Nicola M, Alsafi Z, Sohrabi C, Kerwan A, Al-Jabir A, Iosifidis C, Agha M, Agha R (2020) The socio-economic implications of the coronavirus pandemic (COVID-19): A review. International Journal of Surgery 78: 185-193.

Nieto-Torres JL, Dediego ML, Alvarez E, Jiménez-Guardeño JM, Regla-Nava JA, Llorente M, Kremer L, Shuo S, Enjuanes L (2011) Subcellular location and topology of severe acute respiratory syndrome coronavirus envelope protein. Virology 415(2):69-82. doi: 10.1016/j.virol.2011.03.029.

Nikhra V (2020) Adverse Outcomes for Elderly in Covid-19: The Loss of the Longevity Dream. DOI: 10.13140/RG.2.2.34684.08328/1.

Ogen Y (2020) Assessing nitrogen dioxide $\left(\mathrm{NO}_{2}\right)$ levels as a contributing factor to coronavirus (COVID-19) fatality. Science of the Total Environment 726:138605. doi: 10.1016/j.scitotenv.2020.138605.

Omolo CA, Soni N, Fasiku VO, Mackraj I, Govender T (2020) Update on therapeutic approaches and emerging therapies for SARS-CoV-2 virus. European Journal of Pharmacology 173348. doi: 10.1016/j.ejphar.2020.173348.

Patel SK, Saikumar G, Rana J, Dhama J, Yatoo MI, Tiwari R, Rodríguez-Morales AJ, Dhama K (2020b) Dexamethasone: A boon for critically ill COVID-19 patients? Travel Medicine and Infectious Disease 37:101844. doi: 10.1016/j.tmaid.2020.101844.

Patel SK, Singh R, Rana J, Tiwari R, Natesan S, Harapan H, Arteaga-Livias K, Bonilla-Aldana DK, Rodríguez-Morales AJ, Dhama K (2020a) The kidney and COVID-19 patients - important considerations. Travel Medicine and Infectious Disease 101831. doi: 10.1016/j.tmaid.2020.101831.

Persinger RL, Poynter ME, Ckless K, Janssen-Heininger YM (2002). Molecular mechanisms of nitrogen dioxide induced epithelial injury in the lung. Molecular and Cellular Biochemistry 234(1): 71-80.

Prasad A, Muthamilarasan M, Prasad M (2020) Synergistic antiviral effects against SARS-CoV-2 by plant-based molecules. Plant Cell Reports 1-6. doi: 10.1007/s00299-020-02560-w. 
Prompetchara E, Ketloy C, Palaga T (2020) Immune responses in COVID-19 and potential vaccines: Lessons learned from SARS and MERS epidemic. Asian Pacific Journal of Allergy and Immunology 38(1):1-9. doi:10.12932/AP-200220-0772

Qamar SA, Basharat K, Bilal M, Iqbal HMN (2020) Therapeutic modalities for sARs-Cov-2 (COVID-19): Current status and role of protease inhibitors to block viral entry into host cells. Journal of Pure and Applied Microbiology 1695-1703.

Qiu P, Zhou Y, Wang F, Wang H, Zhang M, Pan X, Zhao Q, Liu J (2020) Clinical characteristics, laboratory outcome characteristics, comorbidities, and complications of related COVID-19 deceased: a systematic review and meta-analysis. Aging Clinical and Experimental Research doi: 10.1007/s40520-020-01664-3.

Rastogi S, Pandey DN, Singh RH (2020) COVID-19 Pandemic: A pragmatic plan for Ayurveda Intervention. Journal of Ayurveda and Integrative Medicine https://doi.org/10.1016/j.jaim.2020.04.002.

Razonable RR (2011) Antiviral drugs for viruses other than human immunodeficiency virus. Mayo Clinic Proceedings 86(10) : 10091026).

Rizwan K, Rasheed T, Khan SA, Bilal M, Mahmood T (2020) Current perspective on diagnosis, epidemiological assessment, prevention strategies, and potential therapeutic interventions for severe acute respiratory infections caused by 2019 novel coronavirus (SARS-CoV-2). Human Vaccines \& Immunotherapeutics, 1-10.

Rodriguez-Morales AJ, Bonilla-Aldana DK, Tiwari R, Sah R, Rabaan AA, Dhama K (2020) COVID-19, an Emerging Coronavirus Infection: Current Scenario and Recent Developments - An Overview. Journal of Pure and Applied Microbiology 14(1): 05-12.

Rogers CJ, Harman RJ, Bunnell BA, Schreiber MA, Xiang C, Wang FS, Santidrian AF, Minev BR (2020) Rationale for the clinical use of adipose-derived mesenchymal stem cells for COVID-19 patients. Journal of Translational Medicine 18(1):203. doi: 10.1186/s12967-020-02380-2.

Rogosnitzky M, Okediji P, Koman I (2020) Cepharanthine: a review of the antiviral potential of a Japanese-approved alopecia drug in COVID-19. Pharmacological Reports 1-8. doi: 10.1007/s43440-020-00132-z.

Ronco C, Reis T (2020) Kidney involvement in COVID-19 and rationale for extracorporeal therapies. Nature Reviews Nephrology 16(6):308-310. doi: 10.1038/s41581-020-0284-7.
Roujian L, Xiang Z, Juan L, Peihua N, BoY, HonglongW, Yuhai B, et al. (2020) Genomic characterization and epidemiology of 2019 novel coronavirus: implications for virus origins and receptor binding. The Lancet 395(10224): 565-574.

Rubenfeld GD, Caldwell E, Peabody E, Weaver J, Martin DP, Neff M, Hudson LD (2005) Incidence and outcomes of acute lung injury. New England Journal of Medicine 353(16): 1685-1693.

Runfeng L, Yunlong H, Jicheng H, Weiqi P, Qinhai M, Yongxia S, Chufang L, Jin Z, Zhenhua J, Haiming J, Kui Z, Shuxiang H, Jun D, Xiaobo L, Xiaotao H, Lin W, Nanshan Z, Zifeng Y (2020) Lianhua Qingwen exerts anti-viral and anti-inflammatory activity against novel coronavirus (SARS-CoV-2). Pharmacological Research 156:104761. doi: 10.1016/j.phrs.2020.104761.

Saha P, Banerjee AK, Tripathi PP, Srivastava AK, Ray U (2020) A virus that has gone viral: an amino acid mutation in $\mathrm{S}$ protein of Indian isolate of Coronavirus COVID-19 might impact receptor binding, and thus, infectivity. Bioscience Reports 40(5):BSR20201312. doi: 10.1042/BSR20201312.

Sanders JM, Monogue ML, Jodlowski TZ, Cutrell JB (2020) Pharmacologic Treatments for Coronavirus Disease 2019 (COVID-19): A Review. Journal of American Medical Association. doi: 10.1001/jama.2020.6019.

Savarino A, Boelaert JR, Cassone A, Majori G, Cauda R (2003) Effects of chloroquine on viral infections: an old drug against today's diseases? Lancet Infectious Disease 3(11):722-7. doi: 10.1016/s1473-3099(03)00806-5.

Savarino A, Di Trani L, Donatelli I, Cauda R, Cassone A (2006) New insights into the antiviral effects of chloroquine. Lancet Infectious Disease 6(2):67-9. doi: 10.1016/S1473-3099(06)70361-9.

Sawicki SG, Sawicki DL, Siddell SG (2007) A contemporary view of coronavirus transcription. Journal of Virology 81(1): 20-29.

Schijns V, Lavelle EC (2020) Prevention and treatment of COVID19 disease by controlled modulation of innate immunity. European Journal of Immunology 50(7):932-938. doi: 10.1002/eji.202048693.

Sethna PB, Hofmann MA, Brian DA (1991) Minus-strand copies of replicating coronavirus mRNAs contain anti leaders. Journal of virology 65(1): 320-325.

Shah STA, Mansoor M, Mirza AF, Dilshad M, Khan MI, Farwa R, Iqbal HM (2020) Predicting COVID-19 Spread in Pakistan using the SIR Model. Journal of Pure and Applied Microbiology 14(2). 
Shahbaz M, Bilal M, Akhlaq M, Moiz A, Zubair S, Iqbal, HM (2020a) Strategic Measures for Food Processing and Manufacturing Facilities to Combat Coronavirus Pandemic (COVID-19). Journal of Pure and Applied Microbiology 14(2).

Shahbaz M, Bilal M, Moiz A, Zubair S, Iqbal HM. (2020b) Food Safety and COVID-19: Precautionary Measures to Limit the Spread of Coronavirus at Food Service and Retail Sector. Journal of Pure and Applied Microbiology, 6203.

Shanmugaraj B, Siriwattananon K, Wangkanont K, Phoolcharoen W (2020) Perspectives on monoclonal antibody therapy as a potential therapeutic intervention for Coronavirus disease-19 (COVID-19). Asian Pacific Journal of Allergy and Immunology 1. 10-8.https://doi.org/10.12932/AP-200220-0773.

Sharun K, Tiwari R, Iqbal Yatoo M, Patel SK, Natesan S, Dhama J, Malik YS, Harapan H, Singh RK, Dhama K (2020) Antibodybased immunotherapeutics and use of convalescent plasma to counter COVID-19: advances and prospects. Expert Opinion in Biological Therapy 1-14. doi: 10.1080/14712598.2020.1796963.

Sheahan TP, Sims AC, Zhou S, Graham RL, Pruijssers AJ, Agostini ML, Leist SR, Schäfer A, Dinnon KH 3rd, Stevens LJ, Chappell JD, Lu X, Hughes TM, George AS, Hill CS, Montgomery SA, Brown AJ, Bluemling GR, Natchus MG, Saindane M, Kolykhalov AA, Painter G, Harcourt J, Tamin A, Thornburg NJ, Swanstrom R, Denison MR, Baric RS (2020) An orally bioavailable broad-spectrum antiviral inhibits SARS-CoV-2 in human airway epithelial cell cultures and multiple coronaviruses in mice. Science Translational Medicine 12(541):eabb5883. doi: 10.1126/scitranslmed.abb5883.

Shen C, Wang Z, Zhao F, Yang Y, Li J, Yuan J, Wang F, Li D, Yang M, Xing L, Wei J, Xiao H, Yang Y, Qu J, Qing L, Chen L, Xu Z, Peng L, Li Y, Zheng H, Chen F, Huang K, Jiang Y, Liu D, Zhang Z, Liu Y, Liu L (2020) Treatment of 5 Critically Ill Patients With COVID-19 With Convalescent Plasma. Journal of American Medical Association 323(16):1582-9. doi: 10.1001/jama.2020.4783.

Shin S, Bai L, Oiamo TH, Burnett RT, Weichenthal S, Jerrett M, Chen H (2020) Association between road traffic noise and incidence of diabetes mellitus and hypertension in Toronto, Canada: a population-based cohort study. Journal of the American Heart Association 9(6): e013021.

Simas PVM, de Souza Barnabé AC, Durães-Carvalho R, de Lima Neto DF, Caserta LC, Artacho L, Ferreira HL (2015) Bat coronavirus in Brazil related to the Appalachian ridge and Porcine epidemic diarrhea viruses. Emerging infectious diseases 21(4): 729.

Snijder EJ, Bredenbeek PJ, Dobbe JC, Thiel V, Ziebuhr J, Poon LL, Gorbalenya AE (2003) Unique and conserved features of genome and proteome of SARS-coronavirus, an early split-off from the coronavirus group 2 lineage. Journal of Molecular Biology 331(5): 991-1004.

Snijder EJ, Van Der Meer Y, Zevenhoven-Dobbe J, Onderwater JJ, van der Meulen J, Koerten HK, Mommaas AM (2006) Ultrastructure and origin of membrane vesicles associated with the severe acute respiratory syndrome coronavirus replication complex. Journal of Virology 80(12): 5927-5940.

Song HD, Tu CC, Zhang GW, Wang SY, Zheng K, Lei LC, Chen QX, Gao YW, Zhou HQ, Xiang H, Zheng HJ (2005) Cross-host evolution of severe acute respiratory syndrome coronavirus in palm civet and human. Proceedings of the National Academy of Sciences 102(7):2430-5.

Song W, Gui M, Wang X, Xiang Y (2018) Cryo-EM structure of the SARS coronavirus spike glycoprotein in complex with its host cell receptor ACE2. PLoS Pathogens 14(8): e1007236.

Su S, Wong G, Shi W, Liu J, Lai AC, Zhou J, Gao GF (2016) Epidemiology, genetic recombination, and pathogenesis of coronaviruses. Trends in Microbiology 24(6): 490-502.

Tang N, Bai H, Chen X, Gong J, Li D, Sun Z (2020) Anticoagulant treatment is associated with decreased mortality in severe coronavirus disease in 2019 patients with coagulopathy. Journal of Thrombosis and Haemostasis 18(5):1094-1099. doi: $10.1111 /$ jth. 14817 .

Tarar SH, Atta H, Khalid M, Saeed S, Shah SMA, Rizwan K, Bilal M (2020) A case report of pregnant lady having COVID-19 delivered via Cesarean section in tertiary care hospital in Pakistan. Journal of Pure and Applied Microbiology 14(2): 11211123.

Tekes G, Thiel HJ (2016) Feline coronaviruses: Pathogenesis of feline infectious peritonitis. Advances in Virus Research, Coronaviruses 96: 193-218. Doi: 10.1016/bs.aivir.2016.08.002

Tisoncik JR, Korth MJ, Simmons CP, Farrar J, Martin TR, Katze MG (2012) In to the eye of the cytokine storm. Microbiology and Molecular Biology Reviews 76(1):16-32.

Tiwari R, Dhama K, Sharun K, Iqbal Yatoo M, Malik YS, Singh R, Michalak I, Sah R, Bonilla-Aldana DK, Rodriguez-Morales AJ (2020) COVID-19: animals, veterinary and zoonotic links. Veterinary Quarterly 40(1):169-182. doi: $10.1080 / 01652176.2020 .1766725$.

Tiwari R, Latheef SK, Ahmed I, Iqbal HMN, Bule MH, Dhama K, Samad HA, Karthik K, Alagawany M, El-Hack MEA, Yatoo MI, Farag MR (2018) Herbal Immunomodulators - A Remedial Panacea 
for Designing and Developing Effective Drugs and Medicines: Current Scenario and Future Prospects. Current Drug Metabolism 19(3):264 301. doi: 10.2174/1389200219666180129125436.

Vellingiri B, Jayaramayya K, Iyer M, Narayanasamy A, Govindasamy V, Giridharan B, Ganesan S, Venugopal A, Venkatesan D, Ganesan H, Rajagopalan K, Rahman PKSM, Cho SG, Kumar NS, Subramaniam MD (2020) COVID-19: A promising cure for the global panic. Science of the Total Environment 725:138277.

Wang C, Horby PW, Hayden FG, Gao GF (2020d) A novel coronavirus outbreak of global health concern. The Lancet 395(10223): 470-473.

Wang C, Li W, Drabek D, Okba NMA, van Haperen R, Osterhaus ADME, van Kuppeveld FJM, Haagmans BL, Grosveld F, Bosch BJ (2020c) A human monoclonal antibody blocking SARS-CoV-2 infection. Nature Communication 11(1):2251. doi: 10.1038/s41467-020-16256-y.

Wang J, Zhu L, Liu L, Zhao XA, Zhang Z, Xue L, Yan X, Huang S, Li Y, Cheng J, Zhang B, Xu T, Li C, Ji F, Ming F, Zhao Y, Shao H, Sang D, Zhao H, Guan X, Chen X, Chen Y, Issa R, Wei J, Huang R, Zhu C, Wu C (2020e) Overweight and obesity are risks factors of severe illness in patients with COVID-19. Obesity (Silver Spring). doi: 10.1002/oby.22979.

Wang M, Cao R, Zhang L, Yang X, Liu J, Xu M, \& Xiao G (2020b) Remdesivir and chloroquine effectively inhibit the recently emerged novel coronavirus $(2019-\mathrm{nCoV})$ in vitro. Cell Research 30(3): 269-271.

Wang Q, Zhang Y, Wu L, Niu S, Song C, Zhang Z,Lu G, Qiao C, Hu Y, Yuen K-Y, Wang Q, Zhou H, Yan J, Jianxun Qi J (2020a) Structural and functional basis of SARS-CoV-2 entry by using human ACE2. Cell 181(4): 894-904.e9. doi: 10.1016/j.cell.2020.03.045

Watanabe S, Masangkay JS, Nagata N, Morikawa S, Mizutani T, Fukushi S, Alviola P, Omatsu T, Ueda N, Iha K, Taniguchi S (2010) Bat coronaviruses and experimental infection of bats, the Philippines. Emerging Infectious Diseases 16(8):1217.

Watanabe Y, Allen JD, Wrapp D, McLellan JS, Crispin M (2020) Site-specific glycan analysis of the SARS-CoV-2 spike. Science 369(6501):330-333.

Weis N, Thorsteinsson K, Martinussen C, Madsbad S (2020) The endocrine and metabolic link between COVID-19, diabetes, and obesity. UgeskrLaeger 182(29): V05200381.

Woo PC, Lau SK, Lam CS, Lau CC, Tsang AK, Lau JH, Bai R, Teng JL., Tsang, C. C. \& other authors (2012). Discovery of seven novel mammalian and avian coronaviruses in the genus Deltacoronavirus supports bat coronaviruses as the gene source of Alphacoronavirus and Betacoronavirus and avian coronaviruses as the gene source of Gammacoronavirus and Deltacoronavirus. Journal of Virology 86: 3995-4008.

World Health Organization (2003) Health aspects of air pollution with particulate matter, ozone, and nitrogen dioxide: report on a WHO working group, Bonn, Germany 13-15 January 2003 (No. EUR/03/5042688). Copenhagen: WHO Regional Office for Europe.

Wu D, Lewis ED, Pae M, Meydani SN (2019) Nutritional Modulation of Immune Function: Analysis of Evidence, Mechanisms, and Clinical Relevance. Frontiers in Immunology 9:3160.

Wu Y, Wang F, Shen C, Peng W, Li D, Zhao C, Li Z, Li S, Bi Y, Yang Y, Gong Y, Xiao H, Fan Z, Tan S, Wu G, Tan W, Lu X, Fan C, Wang Q, Liu Y, Zhang C, Qi J, Gao GF, Gao F, Liu L (2020) A non-competing pair of human neutralizing antibodies block COVID-19 virus binding to its receptor ACE2. Science 368(6496):1274-1278. doi: 10.1126/science.abc2241.

Xiong X, Wang P, Su K, Cho WC, Xing Y (2020) Chinese herbal medicine for coronavirus disease 2019: A systematic review and meta-analysis. Pharmacological Research 160:105056. doi: 10.1016/j.phrs.2020.105056.

Xu J, Shi PY, Li H, Zhou J (2020a) Broad-Spectrum Antiviral Agent Niclosamide and Its Therapeutic Potential. ACS Infectious Diseases 6(5):909-915. doi: 10.1021/acsinfecdis.0c00052.

Xu X, Han M, Li T, Sun W, Wang D, Fu B, Zhou Y, Zheng X, Yang Y, Li X, Zhang X, Pan A, Wei H (2020b) Effective treatment of severe COVID-19 patients with tocilizumab. Proceedings of the National Academy of Science U S A 117(20):10970-10975. doi: 10.1073/pnas.2005615117.

Yamin M (2020) Counting the cost of COVID-19. International Journal of Information Technology 1-7. doi: 10.1007/s41870-02000466-0.

Yang J, Zheng Y, Gou X, Pu K, Chen Z, Guo Q, Ji R, Wang H, Wang Y, Zhou Y (2020) Prevalence of comorbidities and its effects in patients infected with SARS-CoV-2: a systematic review and meta-analysis. International Journal of Infectious Disease 94:91-95. doi: 10.1016/j.ijid.2020.03.017.

Yatoo MI, Hamid Z, Parray OR, Wani AH, Ul Haq A, Saxena A, Patel SK, Pathak M, Tiwari R, Malik YS, Sah R, Rabaan AA, Rodriguez Morales AJ, Dhama K (2020) COVID-19 - Recent advancements in identifying novel vaccine candidates and current status of upcoming 
SARS-CoV-2 vaccines. Human Vaccines and Immuno therapeutics 16(12): doi: 10.1080/21645515.2020.1788310.

Ye Q, Wang B, Mao J (2020) The pathogenesis and treatment of the 'Cytokine Storm' in COVID-19. The Journal of Infection 80(6):607-613

Yoshimoto FK (2020). the proteins of severe acute respiratory syndrome coronavirus-2 (SARS CoV-2 or n-COV19), the cause of COVID-19. Protein Journal 39: 198-216.

Yuan M, Wu NC, Zhu X, Lee CC, So RT, Lv H, Mok CK, Wilson IA. (2020) A highly conserved cryptic epitope in the receptor binding domains of SARS-CoV-2 and SARS-CoV. Science 368(6491):630-3.

Zhang J, Wu W, Zhao X, Zhang W (2020b) Recommended psychological crisis intervention response to the 2019 novel coronavirus pneumonia outbreak in China: a model of West China Hospital. Precision Clinical Medicine 3(1): 3-8.

Zhang S, Yi C, Li C, Zhang F, Peng J, Wang Q, Liu X, Ye X, Li P, Wu M, Yan Q, Guo W, Niu X, Feng L, Pan W, Chen L, Qu L (2019) Chloroquine inhibits endosomal viral RNA release and autophagy-dependent viral replication and effectively prevents maternal to the fetal transmission of Zika virus. Antiviral Research 169:104547. doi: 10.1016/j.antiviral.2019.104547.
Zhang YZ, Holmes EC (2020a) A genomic perspective on the origin and emergence of SARS-CoV-2. Cell 181(2):223-227. doi: 10.1016/j.cell.2020.03.035.

Zhong J, Tang J, Ye C, Dong L (2020) The immunology of COVID-19: is immune modulation an option for treatment? The Lancet Rheumatology 2(7): E428-E436. https://doi.org/10.1016/S2665-9913(20)30120-X.

Zhou P, Fan H, Lan T, Yang XL, Shi WF, Zhang W, Zheng XS (2018) Fatal swine acute diarrhea syndrome is caused by an HKU2-related coronavirus of bat origin. Nature 556(7700), 255258.

Zhou P, Yang XL, Wang XG, Hu B, Zhang L, Zhang W, Chen HD (2020b) A pneumonia outbreak is associated with a new coronavirus of probable bat origin. Nature 579(7798): 270-273.

Zhou P, Yang XL, Wang XG, Hu B, Zhang L, Zhang W, Si HR, Zhu Y, Li B, Huang CL, Chen HD (2020a) Discovery of a novel coronavirus associated with the recent pneumonia outbreak in humans and its potential bat origin. BioRxiv 2020 Jan 1.https://doi.org/10.1101/2020.01.22.914952.

Ziebuhr J, Snijder EJ, Gorbalenya AE (2000) Virus-encoded proteinases and proteolytic processing in the Nidovirales. Journal of General Virology 81(4): 853-879. 